\title{
Myślenie za pomocą reprezentacji zewnętrznych
}

\author{
David Kirsh \\ Uniwersytet Kalifornijski w San Diego \\ kirsh[]ucsd.edu \\ Przekład: Łukasz Afeltowicz
}

(Tekst oryginalny pt. „Thinking with external representations” ukazał się w Artificial Intelligence and the Simulation of Behaviour (2010) 25: 441-454 ${ }^{30}$ )

Przekład zaakceptowano: czerwiec 2014; opublikowano: lato 2014.

\begin{abstract}
Abstrakt
Dlaczego ludzie tworzą reprezentacje zewnętrzne, by pomóc sobie w zrozumieniu sytuacji, diagramów, ilustracji, poleceń czy problemów? Oczywisty powód jest taki, że reprezentacje zewnętrzne odciążają naszą wewnętrzną pamięć i obliczenia - to jednak tylko część wyjaśnienia. Omawiam tu siedem sposobów, za pomocą których reprezentacje zewnętrzne zwiększają nasze możliwości poznawcze: (1) zmieniają strukturę kosztów w procesie wnioskowania; (2) wyposażają nas w struktury, które mogą funkcjonować jako współdzielone z innymi przedmioty myśli, (3) tworzą trwałe desygnaty, (4) ułatwiają proces reprezentowania, (5) oddają struktury w sposób bardziej naturalny niż reprezentacje umysłowe, (6) umożliwiają bardziej przejrzyste sposoby kodowania informacji; (7) pozwalają na tworzenie struktur o dowolnej złożoności; (8) obniżają koszty kontroli procesów myślowych: ułatwiają koordynowanie myśli. Łącznie funkcje te sprawiają, że ludzie są w stanie lepiej myśleć za pomocą reprezentacji zewnętrznych niż bez nich. Pozwalają nam myśleć o rzeczach pierwotnie nie do pomyślenia.
\end{abstract}

Słowa kluczowe: reprezentacje zewnętrzne; myślenie; interakcyjność; rozumienie; struktura kosztów.

\footnotetext{
${ }^{30}$ Przekład publikowany za zgodą właścicieli praw do tekstu.
} 


\section{Wprowadzenie}

Esej ten jest próbą wyjaśnienia, dlaczego myślenie i rozumienie tak często mają charakter interaktywny. Przez interaktywność rozumiem proces przebiegający obustronnie: ktoś zmienia otaczający go świat, ten ostatni zwrotnie zmienia tę osobę, a wszystko to jest w ciągłej dynamice. Zgodnie z moim rozumieniem czytanie tekstu $\mathrm{w}$ ciszy nie jest czynnością interaktywną: niewątpliwie mamy tu do czynienia z działaniem, ale jeszcze nie z interakcją. Przykładami procesów interaktywnych są za to lektura tekstu połączona z podkreślaniem fragmentów, czytanie i podsumowywanie tekstu, a nawet czytanie tekstu [wspomagane] poruszaniem wargami.

W kontekście interakcji pojawia się następujący problem dotyczący pojmowania i myślenia. Mając do czynienia z zamkniętym światem złożonym z osoby oraz reprezentacji zewnętrznej (diagramu, ilustracji, ustnej instrukcji czy zapisanego opisu problemu), dlaczego ludzie mieliby robić coś więcej poza myśleniem wewnątrz własnych głów? Jeżeli założymy, że nie ma nikogo, komu można zadać pytanie, żadnego narzędzia, które wygenerowałoby jakieś nowe rezultaty, zegara odmierzającego czas czy procesu, który można uruchomić i obserwować jego efekty, więc nie ma niczego zewnętrznego - żadnej wyroczni czy narzędzia - czegoś, z czym można by się skonsultować lub co można by wykorzystać w celu uzyskania dodatkowej porcji informacji. Środowisko nie zawiera niczego, czego nie można by [przywołać] w toku refleksji, przynajmniej teoretycznie. Dlaczego mamy zatem trudzić się zaznaczaniem, gestykulowaniem, wskazywaniem, mówieniem pod nosem, manipulowaniem bezwładną reprezentacją, robieniem notatek i komentarzy, przestawianiem przedmiotów i tak dalej? Dlaczego nie siedzieć bez ruchu i po prostu „myśleć”?

Rysunek 1a ilustruje sytuację, gdy interakcja jest bardzo prawdopodobna. Osobnik słyszy zdanie $\mathrm{S}_{1}$ :

Podstawowa własność trójkąta prostokątnego jest taka, że długość środkowej wychodzącej z kąta prostego w stronę przeciwprostokątnej ma długość połowy długości przeciwprostokątnej.

Co robią ludzie, by zrozumieć, o co chodzi w tym twierdzeniu? Osoby obdarzone wyobraźnią i mające pojęcie o geometrii po kilkukrotnym jego przeczytaniu po prostu myślą. Dochodzą do zrozumienia bez interakcji z jakąkolwiek zewnętrzną rzeczą. Jednak większość z nas po prostu sięga po papier i ołówek, by naszkicować prosty diagram, taki jak ten widoczny na rysunku $1 \mathrm{a}$ lub $1 \mathrm{~b}$. Dlaczego? Gdyby chodziło o stwierdzenie „Zupa się wygotowuje” lub „Kwadrat o wymiarach 4 na 4 jest większy niż kwadrat o wymiarach 3 na 3", zapewne nikt by nie zadawał sobie trudu; zrozumienie problemu byłoby czymś automatycznym. 
Ilustracja 1
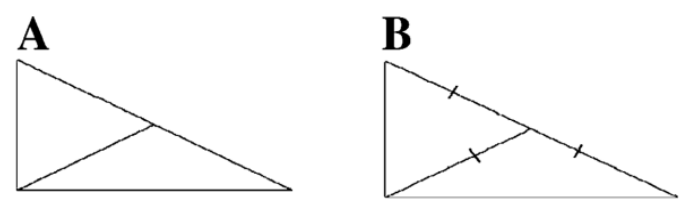

Łatwiej nam zrozumieć zdanie: „W trójkącie prostokątnym długość środkowej wychodzącej z kąta prostego w stronę przeciwprostokątnej ma długość połowy długości przeciwprostokątnej”, jeżeli narysujemy trójkąt i środkową. Ilustracja nie oddaje ogólności twierdzenia, jednak pomaga nam w przekonaniu samych siebie co do jego prawdziwości. Na rysunku $b$ połowy odcinków dodatkowo zostały wyraźnie oznaczone, dzięki czemu twierdzenie jest jeszcze łatwiejsze do odczytania; służy to jako wskazówka w toku rozwiązywania problemu.

Każdy zwolennik poznania usytuowanego (Robbins i Ayedede 2009), rozproszonego (Hollan i in. 2000) czy rozszerzonego (Clark 2008) ma gotową odpowiedź na to pytanie. Procesy poznawcze są realizowane w sposób najtańszy z możliwych. Ludzki „poznawczy system operacyjny” rozszerza się na stany, struktury i procesy poza ludzkim ciałem i umysłem (Giere 2004). Jeśli łatwiej mu pojąć twierdzenie, rysując pomocny diagram, to właśnie to zrobi, zamiast wyłącznie myśleć o nim w swojej głowie. Mamy tu do czynienia z analogią do systemu komputerowego, który posiada systemy pamięci oraz obszary robocze rozlokowane na różnych nośnikach i w różnych miejscach. Decyzja o tym, czy przeprowadzić obliczenia w jednym, czy w kilku obszarach roboczych, uzależniona jest od rodzaju operatorów dostępnych w poszczególnych obszarach, kosztu operacji oraz dostępności przestrzeni dla obliczeń. Procesy powinny być przemieszczane do miejsc, gdzie można je przeprowadzić najskuteczniej lub najłatwiej.

Tego typu ujęcie poznania rozszerzonego lub rozproszonego pokazano sugestywnie na rysunku 2. Zakorzenieni w środowisku, ludzie są w ścisły sposób dopasowani do swojego otoczenia. Procesy poznawcze przesuwają się w miejsca, w których rachunek kosztów [ich realizacji] jest najkorzystniejszy (Russell i in. 1993; Pirolli 2007). Wszystko sprowadza się do rozkładu kosztów obliczeń w każdym z wzajemnie powiązanych podsystemów. Gdy papier i ołówek są poręczne, gdy stwierdzenie jest dość złożone, opłaca nam się zrobić dobrą ilustrację; dzięki temu całkowity poznawczy koszt zrozumienia problemu jest niższy.

Choć uważam to wyjaśnienie za zasadniczo poprawne, jest to tylko jedna z przyczyn, dla których ludzie wchodzą w interakcję z reprezentacjami zewnętrznymi. Inne przyczyny mają związek z przekształceniem samej topografii poznania i zmieniają dużo więcej niż struktura kosztów. Przede wszystkim (a) zyskujemy dostęp do nowych operatorów: na zewnątrz możemy zrobić rzeczy, których nie jesteśmy w stanie zrealizować wewnątrz; (b) [na zewnątrz] możemy kodować struktury o złożoności wyższej niż bylibyśmy w stanie za- 
kodować wewnątrz, a zewnętrzne mechanizmy pozwalają nam na swego rodzaju zainstalowanie nowych pojęć oraz nowych sposobów manipulowania nimi; ewentualnie (c) na zewnątrz możemy realizować czynności z większą precyzją, szybciej, przez okres dłuższy niż wewnątrz: możemy wykorzystać świat, by symulować procesy, których nie moglibyśmy symulować za pomocą wyobraźni lub robić tego równie dobrze. Mówiąc w skrócie, wymienione alternatywne sposoby prowadzą do zmiany dziedziny i zakresu naszego poznania. Stwierdzenie to jest brzemienne $\mathrm{w}$ konsekwencje. Wynika $\mathrm{z}$ niego, że wraz ze zmianą naszego otoczenia oraz technologii będziemy potrafili pomyśleć o rzeczach, o których w tej chwili pomyśleć nie jesteśmy w stanie.

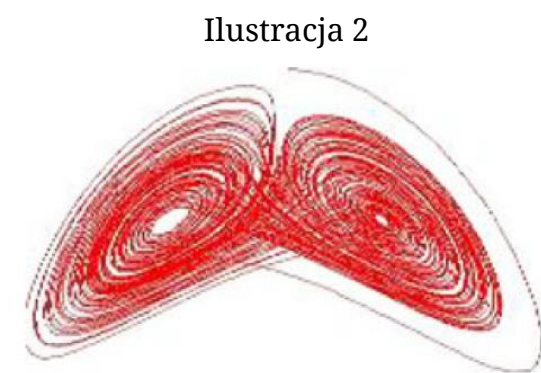

Ten wykres fazowy reprezentuje trajektorię w czasie wybranych procesów poznawczych sprzężonego systemu. Procesy przemieszczają się z jednej strony na drugą za każdym razem, gdy po danej stronie koszt realizacji operacji jest niższy.

Istnieją również inne powody, dla których ludzie wchodzą w interakcje z reprezentacjami zewnętrznymi: przygotowują się w ten sposób do koordynowania wewnętrznych i zewnętrznych stanów, struktur oraz procesów. Ta cecha interakcji jest kluczowa dla zrozumienia reprezentacji zewnętrznych, jednak rzadko poświęca się jej uwagę (zob. Kirsh 2009a,c). Na przykład zanim posłużymy się mapą w celu odnalezienia drogi, zazwyczaj odnosimy ją w jakiś sposób do otoczenia; ustawiamy ją tak, by wytworzyć korzystną zgodność między mapą a światem (Koriat i Norman 1984). Ponadto wielu z nas gestykuluje, wskazuje, głośno mówi i tak dalej. W zasadzie żadne $\mathrm{z}$ tych działań nie jest konieczne do ustanowienia zgodności między punktami na mapie a punktami w terenie, które te pierwsze reprezentują. Ruchy gałek ocznych, umysłowe projektowanie oraz inne nieinteraktywne techniki wystarczają do nawigacji $\mathrm{w}$ oparciu o mapę. Mimo to interakcje zewnętrzne są powszechne i stanowią ważny aspekt pojmowania reprezentacji.

Odkryłem, że tego typu „dodatkowe” działania są częste również w sytuacjach, gdy ludzie próbują zrozumieć i wykonać polecenia. Podczas badań pilotażowych odkryliśmy, że badani usiłujący wykonywać instrukcje dotyczące składania origami oddają się działaniom „interpretacyjnym”: przestawiają składaną kartkę i dopasowują względem karty z instrukcją; wskazują na elementy 
przedstawione na instrukcji i skupiają się na odpowiadającym im elementom składanej kartki; mówią pod nosem, gestykulują, przesuwają kartkę w różne strony. Działania te stanowią część procesu przetwarzania znaczenia poleceń.

W pewnej mierze to samo dzieje się, gdy kucharze niebędący ekspertami korzystają z przepisów kulinarnych. Trzymają palec w miejscu, w którym skończyli, przestawiają składniki, aby zakodować w ich rozmieszczeniu porządek, w jakim powinny zostać wykorzystane (Kirsh 1995); odczytują przepis na głos, zadają sobie pytania dotyczące składników oraz przypominają sobie szeptem. Podobne zachowania obserwujemy u osób składających meble. Ludzie nie tylko myślą, a następnie realizują instrukcje. Wykonują również szereg „nadwyżkowych” czynności, które pomagają im w zrozumieniu samych poleceń. Wskazują na coś, mamroczą, przesuwają instrukcję w różne miejsca, porządkują elementy, kodując w ten sposób sekwencję montażu. Działania te nie są ani poboczne, ani przypadkowe; często są one kluczowe dla procesu rozumienia poleceń oraz skutecznej realizacji zadań.

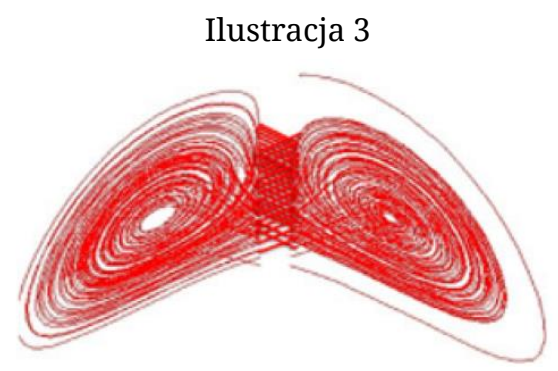

Rysunek sugeruje, że są trzy różne rodzaje kosztów: koszt wewnętrznych operacji na stanach, strukturach, procesach, koszt operacji zewnętrznych oraz koszt koordynacji wewnętrznych i zewnętrznych procesów obejmujący koszt zakotwiczania projekcji oraz koszt kontroli tego, co, kiedy i gdzie należy zrobić.

Jedną z funkcji tych dodatkowych działań jest zakotwiczanie przez ludzi własnej aktywności umysłowej w zewnętrznych względem nich elementach lub procesach. Inna funkcja jest taka, że pomagają dostrzegać konsekwencje instrukcji, głębiej rozumieć polecenia, wreszcie - skuteczniej wprowadzać je w czyn. W obu przypadkach ludzie muszą skoordynować to, co dzieje się wewnątrz ich głów, z tym, co się dzieje na zewnątrz. Ustanawiają odniesienia, koordynują, synchronizują. Owa koordynacja nie odbywa się bezkosztowo. W tym kontekście rysunek 2 prezentuje nam w bardzo uproszczony sposób relację między procesami wewnętrznymi a zewnętrznymi. Należy wziąć pod uwagę jeszcze jeden proces, a mianowicie samo dopasowywanie, czyli działanie mające na celu ustanowienie powiązania poznawczego. Rysunek 3 ilustruje ten nowy, związany z dodatkowymi kosztami proces zakotwiczania (zob. Kirsh 2009b - wstępne omówienie tego trzeciego obszaru kosztów; zob. rów- 
nież Hutchins 2005 - omówienie zjawiska zakotwiczania percepcyjnego, oraz Fauconnier i Turner 2002 - zakotwiczanie w przestrzeniach umysłu).

Proces zakotwiczania czy też ugruntowywania jest niezwykle ważny. Jednak w dalszej części tekstu skupiam się raczej na naszych interakcjach z reprezentacjami służących zmianie samej topografii poznania, mniej natomiast - na interakcjach, które umożliwiają nam wykorzystanie elementów tej topografii poprzez zakotwiczanie.

\section{Materialność i jej konsekwencje}

Jak od dawna przekonuję wraz z innymi [badaczami], ludzie w trakcie myślenia wchodzą $w$ interakcje i tworzą zewnętrzne względem siebie struktury, ponieważ:

Dzięki interakcji możemy przetwarzać wydajniej i skuteczniej niż w sytuacji, gdy działamy tylko wewnątrz naszych głów (Clark 2008; Kirsh 1995, 1996, 2009; Kirsh and Maglio 1994).

Wydajność zazwyczaj rozumiana jest jako korzystny stosunek szybkości wykonania do precyzji. Poznanie interaktywne podnosi wydajność, gdyż z zasady prowadzi do zmniejszenia liczby błędów lub zwiększenia szybkości [działania].

Z kolei przez skuteczność rozumiemy zdolność do radzenia sobie z trudniejszymi problemami. Poznanie interaktywne podnosi skuteczność, ponieważ zwykle umożliwia nam obliczanie w sposób bardziej wnikliwy, precyzyjny, a często też w szerszym spektrum.

Chodzi o to, że korzystając z zewnętrznego materiału - pióra, papieru, linijki a następnie zmierzając do osiągnięcia celów głównych i szczegółowych poprzez wykorzystanie tych materiałów - jak poleceń: narysuj trójkąt, zaznacz połowę długości przeciwprostokątnej - odnosimy korzyść z fizycznych ograniczeń oraz wizualnych podpowiedzi wspomagających procesy poznawcze (Scaife i Rogers 1996). Może to zachodzić na kilka różnych sposobów. Na przykład metoda konstruowania ułatwia interpretację. Działanie jest zasadniczo sekwencyjne, a więc polega na dodawaniu [kolejnych etapów]; struktura wyłania się krok po kroku, a dana osoba musi rozstrzygać [kolejne] określone problemy. Jaka powinna być podstawa i wysokość trójkąta? Czy to ma znaczenie? Czy środkowa ma przepoławiać kąt prosty? Pracując z użyciem narzędzi i zewnętrznych struktur, osadzamy rozumienie w coraz bardziej dookreślonym, konkretnym przypadku. Gdy już określimy wielkość [naszego modelowego] trójkąta prostokątnego, wymóg podzielenia przeciwprostokątnej na pół okazuje się w pełni skonkretyzowany. Brzmi on teraz: „podziel tę konkretną przeciwprostokątną". Ten przyrostowy, interaktywny proces, bogaty w podpowiedzi, wskazówki, widoczne możliwości oraz niemożliwości, dostarcza 
więcej ograniczeń [doprecyzowujących problem] niż umysłowe wydobycie pojęciowej całości z semantyki lub składowych lingwistycznych. Językowe sformułowanie problemu byłoby zdecydowanie ogólniejsze, ale zarazem mniej ograniczone (zob. rysunki 1 i 4).

Drugi sposób, w jaki materialność otoczenia uczestniczy w poznaniu, polega na tym, że silnie angażuje ono korę mózgową wzrokową i motoryczną. Gdy jakaś struktura jest widoczna oraz można ją narysować, jej właściwości prymują całą konstelacje połączeń. Już samo to, że korzystamy z zewnętrznych materiałów - posługujemy się linijką, wykreślamy krzyżujące się linie - a następnie patrzymy na rezultaty naszej pracy, umożliwia nam rozpoznanie pewnych właściwości i możliwości graficznych, które są identyfikowane i torowane. Na przykład dwie przecinające się linie określają zestaw kątów. Uwaga wzrokowa w naturalny sposób skupia się i ocenia te kąty. Czy są one równoważne? Jeśli trójkąt posiada kąt prosty, wtedy automatycznie pobudzony zostaje zestaw pojęć przestrzennych dotyczących trójkątów prostokątnych, co w szczególności dotyczy powiązań wypracowanych w wyniku wcześniejszych doświadczeń z diagramami przedstawiającymi takie trójkąty. Te wzrokowe i fizyczne powiazania mogą być inne i bardziej rozbudowane niż powiązania wypracowane na podstawie słownych opisów [trójkątów prostokątnych]. Jest to szczególnie widoczne, gdy trzymamy jakieś narzędzie w ręce. Linijka prymuje działania i myśli związane z pomiarem, kątomierz toruje drogę myśleniu o kątach i stopniach.

\section{Ilustracja 4}
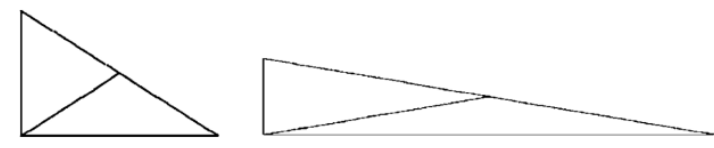

Rysując trójkąt, musimy podjąć szereg decyzji. Ma być długi czy krótki? Równoramienny? Czy którykolwiek z tych wyborów wpłynie na prawdziwość twierdzenia? Konieczność rozstrzygania takich kwestii wspomaga nas w trakcie rozwiązywania problemu.

Korzyści wynikające z interakcji z reprezentacjami zewnętrznymi są szczególnie wyraźne w przypadku złożonych struktur. Gdy wzrasta złożoność językowego opisu struktury wizualnej, coraz bardziej opłaca się nam zrozumieć ów opis poprzez fizyczne rozrysowanie struktury i przyjrzenie się jej niż poprzez próbę skonstruowania obrazu tej struktury w wyobraźni i czysto wewnętrznego zrozumienia znaczenia opisu językowego. Większości ludzi łatwiej przychodzi myślenie w kategoriach fizycznych linii niż ich umysłowych odpowiedników, w szczególności wtedy, gdy linii tych jest dużo lub gdy tworzona przez nie struktura jest złożona. Oczywiście są ludzie, którzy potrafią w swoich głowach wykonać operacje nieosiągalne dla innych, zawsze jednak 
dochodzimy do takiego punktu, po przekroczeniu którego nasze wewnętrzne moce poznawcze zawodzą, a przewagę zyskuje rozwiązywanie problemu zakładające fizyczne, zewnętrzne działanie (zob. Kirsh 2009b). Więc chociaż z logicznego punktu widzenia w zamkniętym systemie, na który składa się świat i dana osoba, po nakreśleniu rysunku nie pojawia się żadna dodatkowa informacja, to jednak w wyniku interakcji dochodzi do istotnych zmian, które pozytywnie wpływają na przebieg procesu poznawczego. Dokładniej zmiany te dotyczą następujących kwestii:

- tego, co pobudzane jest w głowie danej osoby - a więc na co zwraca ona uwagę, co przechowuje w pamięci wzrokowej lub motorycznej, co jest tutaj prymowane - zewnętrzna struktura pobudza ścieżkę wzrokową, która aktywuje oczekiwania, kreśląc strukturę eksponującą kąty, długości, przyczyniając się do rozległych związków poznawczych w korze motorycznej i wzrokowej;

- tego, co zostaje utrwalone na zewnątrz, w zasięgu czyjegoś wzroku lub dotyku - reprezentacja zewnętrzna przechowuje strukturę $\mathrm{w}$ niezmienionej postaci do momentu, w którym zostanie ona wykorzystana; struktura ta nie zanika w taki sposób jak umysłowe modele i procesy, co pozwala na wielokrotne percepcyjne jej badanie;

- tego, jak w wyniku interakcji kodowana jest informacja, zarówno wewnątrz, jak i na zewnątrz - z uwagi na to, że dostępne są struktury zewnętrzne, można wypróbować różne wewnętrzne i zewnętrze sposoby reprezentowania; dwie różne formy mogą wchodzić ze sobą w interakcje, dając nowy ogląd problemu.

Zasadniczą kwestią jest to, że bardzo często jesteśmy w stanie usprawnić nasze myślenie i pojmowanie, tworząc i posługując się zewnętrznymi reprezentacjami oraz strukturami. Działając na zewnątrz, zmieniamy to, co dzieje się wewnątrz; dzięki interakcji możemy myśleć w nowy sposób. Stwierdzenie to może wydać się zaskakująco oczywiste, jednak ze względu na jego zasadniczy charakter oraz daleko idące konsekwencje zasługuje na pogłębioną analizę oraz badania empiryczne.

Pozwolę sobie zatem rozwinąć tę ideę, omawiając siedem różnych korzyści, jakie oferuje nam eksternalizacja struktury.

\section{Współdzielone i identyfikowalne przedmioty myśli}

Gdy ktoś uzewnętrznia strukturę, nie tylko komunikuje się z samym sobą, ale także sprawia, że inni mogą skupić się wraz z nim na tej samej rzeczy. Uzewnętrzniona struktura może być współdzielona $z$ innymi jako obiekt myśli. Takie urzeczowienie tego, co wewnątrz - eksternalizacja - jest korzystna dla obu stron. 
Oto przykład. Na rysunku 5 na pozycje ciała przyjmowane przez tancerza naniesiono widoczne figury geometryczne. Znany choreograf Bill Forsythe $\mathrm{w}$ trakcie wykładu zademonstrował skręty ciała, posługując się nagraniem wideo, które opatrzono dodatkowymi oznaczeniami istotnych części ciała. Najpierw wskazał kluczowe punkty na swoim własnym ciele i omówił je, następnie przeszedł do całych segmentów linii [łączących punkty], takich jak odcinek między łokciem a ręką, które oznaczono na nagraniu, i wreszcie doszedł do kwestii łączenia tych odcinków w trójwymiarowe trapezoidy, które pod postacią takich trójwymiarowych form zaprezentowano widzom na ekranie. Dzięki temu uczestnicy prezentacji mogli z łatwością dostrzec, w jaki sposób ruch taneczny przekłada się na przekształcenia trapezoidu. Forsythe w trakcie omawiania idei skrętów, odchyleń oraz kątów ciała bazował na tym, że słuchacze jednocześnie widzą graficzne adnotacje, trójwymiarowe struktury (Forsythe 2008).

Jedną z zalet tego szczególnego sposobu oznaczania jest to, że gdy już struktury, które mają być manipulowane, zostaną słownie określone przez choreografa i wzrokowo zlokalizowane na własnym ciele, każda osoba oglądająca nagranie zrozumie, do czego odnoszą się dowolne widoczne części trapezoidy. Wtedy widzowie mogą zadawać trafne pytania dotyczące tego, jak widoczne kształty odnoszą się do słów choreografa, lub nawet jak konkretne elementy figur - czubek lub baza - odnoszą się do pewnych abstrakcyjnych idei. Gdy na przykład pewne linie i płaszczyzny zostaną już uzewnętrznione, każdy może zapytać choreografa lub samego siebie, przy jakich pozycjach objętość kształtów geometrycznych pozostanie niezmienna lub podczas jakich ruchów tanecznych górna i dolna płaszczyzna pozostaną równoległe. Dla choreografów pytania tego typu okazują się pomocne, gdy myślą o dynamice ciała oraz gdy próbują przekazać tancerzom koncepcje naprężeń i skrętów. Wszystko to jednak byłoby bardzo trudne do zrozumienia, gdyby grupa nie współdzieliła pewnego wzrokowego lub projektowanego wyobrażenia sposobu, w jaki zmienia się kształt ciała.

\section{Ilustracja 5}
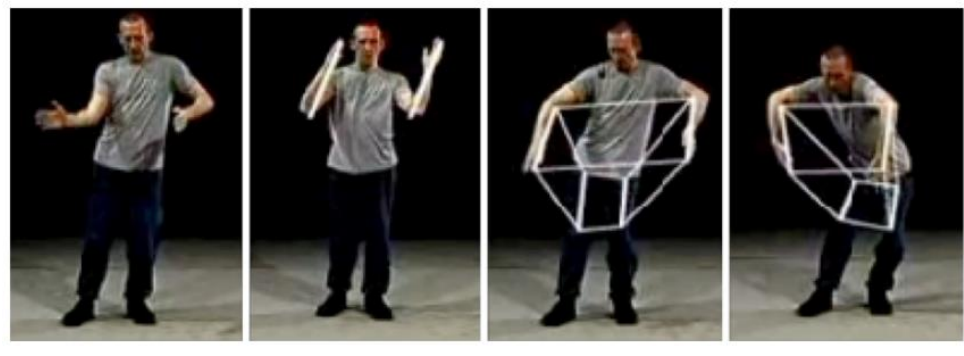

Uznany choreograf Bill Forsythe podjął się filmowej dokumentacji wybranych koncepcji i zasad choreografii. Tu wyjaśnia skręty ciała. Adnotacje wizualne sprawiają, że widzowie mogą z łatwością odnieść się do struktur skądinąd niewidocznych. 
Fizyczna reifikacja kształtu poprzez graficzne adnotacje daje nam coś więcej niż tylko wspólny punkt odniesienia; dzięki temu zabiegowi uzyskujemy trwały element, który można w rzetelny sposób mierzyć, a także wiarygodnie rozpoznawać, identyfikować i reidentyfikować. Pomiar to coś, co robimy, gdy już zidentyfikujemy linię lub strukturę. Nie zawsze wymaga to zewnętrznej obecności. Niektórzy ludzie są w stanie pojąć kształt nakładanej na obraz trapezoidy, po prostu projektując w umyśle niewidzialną strukturę na ciało. Projektują, słuchając wykładowcy i śledząc jego gesty. Jednak nawet osoby, które posiadają wysokie umiejętności wizualizacyjne, odnoszą korzyść z graficznych adnotacji, gdyż to, co uzewnętrznione, oferuje afordancje, które nie są tak naprawdę obecne w trybie projektowania.

Gdy na przykład linie kształtu zostaną uzewnętrznione, możemy zastanawiać się nad długością odcinków oraz kątami między nimi. Wiemy, jak mierzyć je za pomocą linijki i kątomierza. Linie oferują możliwość mierzenia. Jeżeli dana osoba jest w stanie w odpowiedni sposób zakotwiczyć projektowane linie w widocznych punktach [ciała], wówczas możliwy jest pomiar linii w umyśle, choć wcale nie jest to łatwe. Przykładowo choreograf może odnieść się w słowach do długości czyjegoś przedramienia lub dzięki gestykulacji zamarkować całą strukturę bez uciekania się do nagrania wzbogaconego o elementy graficzne. Ale czy może w niezawodny sposób odnieść się do długości linii łączacych górną i dolną płaszczyznę skomplikowanej struktury w sytuacji, gdy płaszczyzny te nie są dostępne wzrokowo? Owe linie muszą zostać zakotwiczone w ciele. Jeśli chodzi o złożoną strukturę, na przykład ściętą piramidę, która ma osiem punktów zakotwiczenia, powinno się ją skonstruować w odpowiedniej sekwencji, tak jak zrobił to Forsythe w swoim nagraniu; w innym przypadku widzowie będą musieli śledzić myślami zbyt wiele rzeczy. Nie przesądza to jeszcze o tym, że takich struktur nie da się identyfikować i markować za pomocą póz i gestów bez pomocy adnotacji wizualnych. Jednak trudność wyobrażania sobie i projektowania w myślach bardzo szybko wzrasta wraz z kolejnymi zakotwiczeniami, lub też kiedy ciało, w którym zakotwiczamy projekcję, jest w ruchu, czy wreszcie - co jest szczególnie trudne - gdy potrzebujemy niewidzialnych punktów zakotwiczenia, co miałoby miejsce chociażby podczas próby wyobrażenia sobie, w jaki sposób ramiona trapezoidy zostają przedłużone i zbiegają się, tworząc szczyt piramidy: wierzchołek unosiłby się w powietrzu, niepołączony z niczym materialnym. Dla odmiany kiedy dana forma zostanie już zaprezentowana $\mathrm{w}$ postać widocznych linii, możemy otwarcie odnosić się do dowolnych elementów kształtu, a nawet je wzrokowo etykietować; możemy je lokalizować, mierzyć, celowo wypaczać, jeśli mamy na to ochotę, a później rozważać efekty tych deformacji. Stają się współdzielonymi przedmiotami myślenia. 
Warto rozwinąć tę kwestię. Stwierdzenie, że coś jest lub może być przedmiotem myśli, zakłada, że podmiot może myślami odnieść się do tej rzeczy, że w jakiś sposób myślący może uchwycić desygnat myśli. [Określenie czegoś jako] współdzielonego obiektu myśli oznacza, że różne osoby współdzielą mechanizmy odniesienia umożliwiające im uzgodnienie atrybutów desygnatu. Na przykład Wilard V. O. Quine (1960) w ślad za Peterem Strawsonem (1959) twierdził, że obiekty muszą posiadać warunki identyczności, zgodnie z jego powiedzeniem: „Nie ma bytu bez [kryterium] identyczności”. Jednostki muszą być identyfikowalne, reidentyfikowalne i wyróżnialne spośród pokrewnych sobie. Czy struktury i adnotacje przedstawione na rysunku 5 spełniałyby te kryteria, gdyby były wyobrażane lub projektowane? To zależy od tego, jak dobrze byłyby zakotwiczone we własnościach fizycznych. Z pewnością istnieją ludzie - choreografowie, tancerze oraz osoby z ponadprzeciętną wyobraźnią - którzy są w stanie utrzymać jasne idee projektowanych struktur i posłużyć się nimi w akcie myślenia. Tak długo, jak „materialne kotwice” pozostają w wystarczającym stopniu stabilne (Hutchins 2005), a ludzie posiadają wystarczająco dużo doświadczenia, by projektować w sposób niezawodny, linie i kształty rzutowane przez ekspertów na widoczne [elementy] środowiska spełniają większość kryteriów „bytowania”, choć twierdzenie to ma charakter wyłącznie empiryczny. Jednak większość z nas przekonuje się, że łatwiej nam myśleć o strukturach, które zostały zreifikowane poprzez wprowadzenie do środowiska pewnych dodatkowych widocznych lub namacalnych elementów. Taka struktura jest dla nas bardziej wyrazista, stabilna i czytelna - lepiej sprawdza się jako przedmiot naszych myśli. Niemal każdy z nas musi zobaczyć linie i kształty, by móc dostrzec łączące je subtelne relacje geometryczne. Dlatego też konstruujemy zewnętrzne struktury. Tworzymy podwaliny dla zupełnie nowych myśli poprzez materializację naszych wstępnych projekcji, tworzenie śladów tych projekcji lub materialną zmianę.

Omawiany tu interaktywny proces polegający na projektowaniu struktur $i$ później na ich materializowaniu jest najbardziej podstawowym z procesów myślowych. Często w trakcie interakcji ze środowiskiem - mających charakter działań epistemicznych - konstruujemy rusztowania dla naszych myśli, struktury, na których możemy się wesprzeć, gdy myślimy. Ale tworzymy również elementy, które mogą działać jako nośniki dla naszych myśli. Posługujemy się nimi jak rzeczami do myślenia.

Nazbyt często niezwykłe korzyści płynące z eksternalizacji i interakcji zostają sprowadzone do nudnych twierdzeń na temat pamięci zewnętrznej. „Czy to wszystko nie sprowadza się przypadkiem do procesu odciążania naszej pamięci?” Takie ujęcie zdecydowanie bagatelizuje zjawiska, z którymi mamy tutaj do czynienia. Każdy wie, że wyjęcie pewnych rzeczy z głowy i przechowywanie ich tam, gdzie są łatwo dostępne, jest pożyteczne. Powszechnie wiadomo, że spisując wnioski lub przelotne myśli, uwalniamy się od potrzeby utrzymywania wszystkich wytworów myślenia w pamięci krótkotrwałej. Jak 
długo ta sama informacja może być obserwowana i wydobywana z naszego otoczenia, tak długo uzewnętrznianie myśli i struktur oszczędza nam kosztów związanych z angażowaniem pamięci roboczej oraz aktywną pamięcią referencyjną.

Jednak pamięć i percepcja to dwie różne rzeczy. Traktowanie informacji znajdującej się wewnątrz oraz na zewnątrz jako tej samej pomija zależną od medium naturę procesu kodowania. Obecnie psychologia przyjmuje, że gdy postrzegamy wzrokowo strukturę zewnętrzną, wówczas informacja, którą wprowadza się do systemu, najpierw jest magazynowana jako wizualnoprzestrzenna (Baddeley 2000; Logie 1995), a dopiero później przetwarzana przez inne procesy umysłowe.

Ponieważ sposób kodowania struktury ma fundamentalny wpływ na to, jak łatwo można ją wykorzystać w jakimś procesie, otwarte pozostaje pytanie, jak wiele potrzeba wewnętrznego przetwarzania, by przekształcić zewnętrzną strukturę w zdatną do użytku strukturę wewnętrzną. W związku z tym nie można bezspornie twierdzić, że koszty zawsze będą niższe, gdy zyskujemy dostęp do informacji percepcyjnie, niż wtedy, gdy zyskujemy do niej dostęp „wewnętrznie”, nawet gdy informacja jest złożona, obszerna i z założenia efektywniej byłoby ją przechowywać na zewnątrz. Wątpliwość ta jest tym bardziej oczywista, gdy jakaś porcja informacji, do której mamy uzyskać dostęp percepcyjny, ukryta jest w gąszczu wizualnych [bodźców]. Wiele będzie zależało od złożoności wzrokowej, sposobu kodowania informacji, od tego, jak łatwo dostrzec strukturę, gdy tego potrzebujemy, i tak dalej. Nawet jeżeli przedmiot myśli reprezentowany jest w sposób jasny i wyraźny - tak jak graficzne adnotacje Forsythe'a - to nadal musi zostać spostrzeżony, zorganizowany w pewną całość i skonceptualizowany. Czy naprawdę znamy relatywną różnicę między kosztem uchwycenia treści reprezentowanych na zewnątrz a kosztem treści wewnętrznych?

Wynika z tego, że świat używany jako zewnętrzny system pamięci może mieć mniejsze znaczenie jako źródło naszych mocy poznawczych niż jako wykorzystywany do przeprowadzania zewnętrznych obliczeń. Rzeczy w świecie zachowują się inaczej niż rzeczy w umyśle. Na przykład reprezentacje zewnętrzne są rozciągłe nie tylko w czasie, ale również w przestrzeni. Możemy posługiwać się nimi na różne sposoby. Można je fizycznie powielać i przestawiać. Możemy dzielić się nimi z innymi ludźmi. Możemy [manipulować] nimi z użyciem narzędzi. Różnice między reprezentacjami wewnętrznymi a zewnętrznymi mają ogromne znaczenie. To właśnie one sprawiają, że interaktywność jest tak interesująca.

Przejdźmy teraz do omówienia tych różnic: możliwości ręcznej zmiany porządku fizycznych tokenów [reprezentujących] komunikaty. Dzięki przestawianiu możemy odkrywać aspekty rozumienia oraz znaczenie - implikacje twierdzenia, które byłyby trudne do wykrycia, gdybyśmy dane zdanie rozwa- 
żali w izolacji, w jego pierwotnej postaci. Zmieniając porządek i układ tego, co znajduje się bliżej lub dalej, zmieniamy bezpośrednie otoczenie tokenu; tym samym zmieniamy przestrzeń rzeczy, które są sobie bliskie lub dalekie w sensie poznawczym.

\section{Przestawianie}

Korzyść wynikająca z fizycznego przestawiania - przynajmniej jeżeli chodzi o nośniki twierdzeń - takie jak zdania, formuły logiczne, relacje obrazowe jest taka, że możemy wzrokowo porównywać twierdzenia utworzone $\mathrm{w}$ różnych momentach oraz zmieniać ich szyk, dzięki czemu łatwiej nam dostrzec związki istotne semantycznie. Na przykład lematy, które w przestrzeni wywodu logicznego są odległe - czyli stanowią wyniki długich wnioskowań z przesłanek i zazwyczaj odkrywane są później, a tym samym uwzględniane w dalszych wierszach - możemy przepisać, umieszczając je w pobliżu twierdzeń wcześniejszych. Dzięki temu odległe od siebie w sensie logicznym twierdzenia mogą znaleźć się bardzo blisko w fizycznym tego słowa znaczeniu. Wprowadzając skrótowce lub definicje, które zastąpią całe sekwencje wierszy, możemy jeszcze bardziej rozszerzyć zakres twierdzeń, które dadzą się wizualnie powiązać ze sobą. Ten proces wnioskowania, powielania, podmieniania, przekształcania, reorganizowania oraz redefiniowania leży u podstaw dowodzenia, poziomów abstrakcji, języka programowania i symbolicznego przetwarzania w ogóle.

Wartość reorganizowania przedstawia rysunek 6. Zadanie polega na ustaleniu, czy sześć elementów widocznych po lewej stronie wystarczy do tego, by po ich ułożeniu powstał obraz widoczny po stronie prawej. Co należy zrobić, aby uzyskać pewność? Skoro problem jest jasno sprecyzowany i nie wymaga żadnych dodatkowych danych, znowu pojawia się pytanie: „dlaczego nie rozwiązać tego w głowie?”. W przypadku rysunku 6 nie mamy wyboru: nie możemy przesuwać elementów układanki, więc niewątpliwie zdamy się na swój wzrok i spróbujemy wyobrazić sobie konsekwencje przesuwania i obracania elementów. Gdyby jednak zadanie przedstawiono w sposób umożliwiający fizyczną manipulację, a więc w postaci ruchomych puzzli, czy nie łatwiej by było dojść do rozwiązania po prostu poprzez podjęcie próby skonstruowania rozwiązania, czyli złożenia rozsypanki, zamiast przepracowywać wszystko wewnętrznie?

Fizyczne przestawianie elementów pozwala analizować relacje, które wcześniej były zbyt odległe lub złożone (dotyczy to między innymi rotacji w umyśle oraz dokładnego dopasowania elementów). Gdy fizycznie przestawiamy puzzle i budujemy z nich całość, problem zostaje sprowadzony do pytania, czy elementy ściśle do siebie pasują. Kwestię tę rozstrzygamy, dopasowując fizycznie elementy i wizualnie oceniając połączenia. Dzięki interakcji świat 
zmienia się z miejsca, w którym dochodzimy do rozwiązań na drodze wewnętrznych obliczeń, $\mathrm{w}$ takie, gdzie istotne właściwości można odkryć dzięki wzrokowi lub dotykowi. Percepcja i działanie zastępują wyobraźnię, projekcję i pamięć, a ruch fizyczny zastępuje umysłowe obliczanie. Zamiast wyobrażać sobie przekształcenia, po prostu wykonujemy je na zewnątrz.
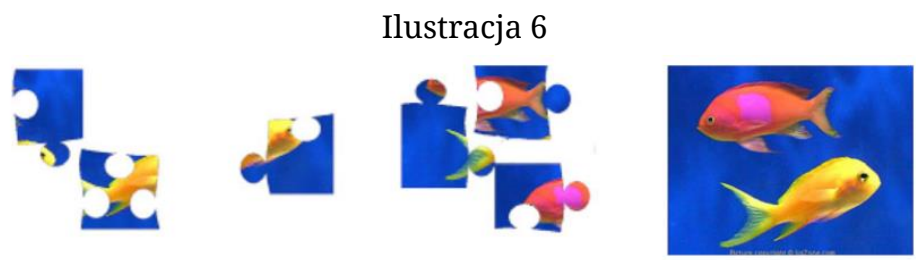

Czy elementy rozsypanki po lewej stronie można idealnie połączyć w obraz taki jak po prawej? Gdybyśmy mogli przestawiać elementy, rozwiązanie byłoby banalne. Odpowiedź brzmi: nie. Czy widzimy, dlaczego? Z jakiego powodu - ogólnie rzecz biorąc zadania tego typu łatwiej rozwiązywać poprzez manipulacje manualne?

Interpretacja korzyści reorganizowania wyłącznie w kategoriach struktury kosztów jest kusząca: czynności poznawcze przenoszone są do świata zewnętrznego, ponieważ tam ich realizacja jest tańsza lub bliższa niezawodności. W wielu przypadkach manipulacja fizyczna jest poznawczo skuteczniejsza i sprawniejsza od manipulacji w umyśle. Wtedy rozsądne jest przeprowadzanie obliczeń na zewnątrz.

Rzeczywiście, w wielu przypadkach przewaga zewnętrznych manipulacji sprowadza się tylko do tego. Na przykład grający w Tetris mogą wybierać między umysłową rotacją tetrazoidów a obracaniem ich w rzeczywistości (Kirsh i Maglio 1995). Z racji tego, że fizyczna rotacja jest nieco szybsza od umysłowej, dodatkowy koszt związany z faktem, że czasami spadający element przekręcimy za daleko, jest więcej niż kompensowany przez korzyści związane z podejmowaniem szybszych i w mniejszym stopniu podatnych na błędy decyzji bazujących na percepcji wzrokowej.

Nie zawsze jednak przewagę zewnętrznych manipulacji daje się sprowadzić wyłącznie do tego. Gdy układamy puzzle, w grę wchodzi coś więcej niż koszty. Wraz ze wzrostem opisowej złożoności planszy dochodzimy do punktu, w którym utrzymanie w umyśle pełnej struktury [problemu] jest bardzo trudne lub wręcz niemożliwe. Już sama próba przesuwania wybranych elementów i ich dopasowywania w myślach sprawia, że wyobrażenie docelowej struktury zaczyna się rozpadać. Wyobraźmy sobie, że składamy w umyśle w całość dwadzieścia oddzielnych elementów puzzli i próbujemy myślami dopasować dwudziesty pierwszy fragment: może okazać się on ziarnkiem przeważającym szalę, prowadzącym do przeładowania i runięcia całej struktury umysłowej. 
Można posłużyć się tu analogią działania obszaru wymiany w systemach komputerowych. W momencie osiągnięcia pewnego progu złożoności efektywność komputera zaczyna gwałtowanie spadać. Może nawet dojść do takiego jej spadku, że komputer nie będzie w stanie rozwiązać problemu, gdyż samo utrzymanie reprezentacji aktualnego stanu problemu pochłonie tyle zasobów, że akt zmiany układu wyczerpie jego pamięć roboczą. Systemowi zabraknie zasobów, by śledzić to, które rozwiązania zostały już wypróbowane, a które dopiero należy sprawdzić. W takiej sytuacji część ułożonej już układanki, która aktualnie nie jest sprawdzana, trzeba zdeponować w pamięci długoterminowej, dzięki czemu system będzie mógł wykonywać kroki programu określające, jakie czynności należy teraz wykonać. Aby następnie wykonać kolejną przewidzianą czynność, system musi wydobyć z pamięci długoterminowej fragment planszy i zamienić go z fragmentem, który sprawdzano uprzednio. Może dojść do tego, że system się zapętli i w nieskończoność będzie podmieniał ten sam zbiór fragmentów planszy, nigdy nie sprawdzając tej jej części, gdzie odnalazłby rozwiązanie problemu. Zerowy postęp.

W przypadku świata fizycznego jest zupełnie inaczej. Dzięki temu, że fizyczne obiekty charakteryzuje pewna trwałość, plansza pozostaje bez zmian, gdy [jedynie] myślimy o ruchach. W przeciwieństwie do reprezentacji umysłowej stabilność stanu fizycznego nie zmienia się $\mathrm{w}$ istotny sposób $\mathrm{w}$ zależności od poziomu złożoności. Układ składający się z dwudziestu jeden puzzli jest tak samo stabilny jak układ dziesięcioelementowy.

Oczywiście świat fizyczny ma również swoje ograniczenia. Gdy już fizycznie zmienimy układ elementów, wcześniejszy stan zostaje utracony, chyba że zostawimy jakiś ślad zmiany w postaci notatki lub utrwalimy poprzedni układ na zdjęciu. A więc szukanie rozwiązania w świecie zewnętrznym nie zawsze jest lepsze niż szukanie go w głowie. Jednak dzięki uzewnętrznieniu wystarczającej liczby stanów - śledząc odpowiednio uważnie zmiany struktury problemu na zewnątrz - możemy ułożyć puzzle, których nie bylibyśmy w stanie złożyć w naszych głowach, bazując tylko na symulacji umysłowej. Możemy rozepchać tę kopertę złożoności dowolnie daleko. Tego nie da się osiągnąć, działając tylko w głowie.

Do kwestii zasadniczych różnic między symulacją umysłową a fizyczną wrócimy pod koniec tekstu.

\section{Fizyczna trwałość i niezależność}

Zarówno czynności reorganizowania, jak i dostęp do stabilnych przedmiotów, za pomocą których można myśleć, zakłada trwałość obiektów fizycznych. W związku z tym kolejną istotną różnicą między reprezentacjami wewnętrznymi a zewnętrznymi, na której powinniśmy się skupić, jest zróżnicowanie stabilności oraz trwałości w czasie. Przestawianie puzzli jest możliwe, gdyż różne 
przekładane fragmenty są obecne w tej samej chwili. Jeśli przed przestawieniem mieliśmy sześć elementów, tyle samo będzie po wykonaniu tej czynności. Dane fragmenty możemy przybliżać do siebie bez zmiany ich właściwości. Nie jest to już tak proste w przypadku myślenia za pomocą fizycznych tokenów zdań, wciąż jednak możemy być pewni, że przestawiając fizycznie nośniki, nie zmieniamy treści samych myśli, do których się odnoszą. Możemy polegać na fizycznej trwałości jako gwarancji tego, że treść nośników zdań nie ulegnie zmianie podczas kopiowania i przesuwania, gdyż ewentualne zmiany możemy z łatwością wykryć, po prostu porównując oryginalne tokeny z ich kopiami, czyli wersje sprzed i po powieleniu. Przy niezmienionych innych warunkach wypowiedź „to zdanie ma pięć wyrazów” znaczy to samo, bez względu na to, czy wydrukowane po lewej, czy prawej stronie, wczoraj czy dziś.

Inaczej jest $\mathrm{w}$ przypadku reprezentacji umysłowych. Dlaczego mamy być pewni tego, że umysłowy obraz $\mathrm{w}$ momencie $t_{1}$ jest tym samym obrazem co $\mathrm{w}$ momencie $t_{0}$ ? I skąd mamy wiedzieć, czy dołączenie nowego wyobrażenia lub zwykła rotacja nie wpłynie na oryginał? Jedynym niezawodnym sposobem potwierdzenia tego jest ustalanie, czy obraz w obu sytuacjach był wywoływany przez tę samą strukturę zewnętrzną. Jeśli brak takiej struktury, wówczas nie ma żadnego probierza, który pozwoliłby obiektywnie stwierdzić, że oba wyobrażenia są identyczne. Jest tylko subiektywne przekonanie. Dla Ludwika Wittgensteina (1953) było to źródło sceptycyzmu względem możliwości poznania własnych wewnętrznych stanów pod nieobecność zewnętrznego odniesienia, które by je ugruntowywało. Nie [można mówić o] wewnętrznych stanach czy procesach bez zewnętrznych kryteriów. A więc bez wsparcia $\mathrm{z}$ zewnątrz może nie być sposobu ustalenia, czy nasze myśli w dwóch różnych momentach są identyczne.

Zatem brutalna rzeczywistość fizycznego trwania zmienia to, co niezawodne, co podzielane, oraz czasową dynamikę myślenia. Jest mniejsza szansa na to, że nasze myśli nie zmieniły się od wczoraj, jeśli kodujący je nośnik lub bodźce je wywołujące również są te same co w dniu wczorajszym. To dlatego pisanie tak pomaga. Gdy nośnikiem myśli jest coś zewnętrznego względem umysłu, możemy polegać na ocenach innych ludzi w kwestii tego, czy [treść] pozostała bez zmian. Podobnie możemy być pewni, że gdy wchodzimy interakcje z reprezentacjami zewnętrznymi lub myślimy o nich, nie ulegają one zmianie; tutaj nasze sądy są bardziej wiarygodne od tych związanych z reprezentacjami wewnętrznymi. W świecie zewnętrznym mamy do czynienia $z$ rozpowszechnionym doświadczeniem dotyczącym wpływu interakcji; wiemy, że istnieje szeroka klasa przekształceń, które nie prowadzą do zmiany treści, jak na przykład rotacja, przesunięcie równoległe czy zmiana oświetlenia. Brakuje jednak podobnych ogólnych zasad dotyczących reprezentacji wewnętrznych. Oznacza to, że mamy większe pojęcie na temat zmian, jakim w wyniku inte- 
rakcji ulegają reprezentacje zewnętrzne, niż podobnych zmian w przypadku reprezentacji wewnętrznych.

Trwałość fizyczna różni się od trwałości tworów umysłowych z ich przelotnością również tym, że zwiększa zakres działań, jakie możemy wykonać względem rzeczy, w której zakodowana jest reprezentacja - czyli nośnika. Na przykład na rysunku 5 ścięty „trójwymiarowy” trapezoid został wykreślony w postaci zestawu linii na ciele choreografa. Zaprezentowano go dzięki technice stopklatek. Pomiar możliwy jest dlatego, że widoczną strukturę - trapezoid zatrzymano $\mathrm{w}$ bezruchu na odpowiednio długi czas. Możemy posłużyć się tutaj narzędziami [pomiarowymi]. Materialność reprezentacji zewnętrznej oferuje takie możliwości działania, które nie dotyczą reprezentacji wewnętrznej.

Architekci, projektanci i inżynierowie, budując modele, wykorzystują zalety trwałości oraz afordancje materiałów. Modele odgrywają specjalną rolę w myśleniu, a na nasze potrzeby możemy postrzegać je jako dwu-, trzy-, a nawet czterowymiarowe reprezentacje zewnętrzne. Są to dwuwymiarowe papierowe szkice, kartonowe modele, animacje, wirtualne oglądy, trójwymiarowe modele przestrzenne i czasowe, a także dynamicznie zmieniające się struktury trójwymiarowe- modele 4D. By pojąć dodatkowe korzyści, jakie oferują tego typu reprezentacje zewnętrzne, przyjrzyjmy się zeskalowanym modelom konstruowanym przez architektów (zob. rysunek 8a).

Owe zeskalowane modele to dotykowe reprezentacje przygotowywanych projektów. Pełnią one kilka funkcji:

1. Ponieważ są niezależne w sensie logicznym i fizycznym od swojego autora, mogą pełnić funkcje współdzielonych obiektów myśli. Mogą być manipulowane, analizowane i obserwowane w sposób odmienny od tego, jaki wyobrażał sobie konstruktor modelu. Jest to kluczowe podczas rozmów z klientami, analizy zachowań i funkcjonalności oraz wykrywania nieprzewidzianych efektów ubocznych projektu. Wspominane elementy projektu stają się przez to czymś upublicznionym i intersubiektywnym.

2. Modele wymuszają spójność. Założenie leżące u podstaw matematycznej teorii modeli głosi, że jeśli można wynaleźć lub stworzyć jakąś strukturę fizyczną, oznacza to, że aksjomaty, które ją ugruntowują, muszą być spójne (Nagel i Newman 1958). W odróżnieniu od opisu świata lub reprezentacji umysłowej dowolny model fizyczny musi byś wewnętrznie spójny. Nie może odnosić się do właściwości, które nie są realizowalne jednocześnie, gdyż jeżeli jest prawidłowym modelem, to jest również dowodem spójności. W wieloelementowym systemie element A nie może być niespójny z elementem B, jeżeli oba mają występować jednocześnie w tej samej nadstrukturze. Podobnie ruch elementu A nie może być niespójny z ruchem B, jeśli oba elementy mogą być poruszane jednocześnie. Poprzez budowanie i uruchamianie czegoś udowad- 
niamy, że jest to możliwe. Niemożliwe jest fizyczne skonstruowanie niespójności. Historycznie rzecz biorąc, nie ma wielu idei, które przemawiałyby z większą siłą niż ta.

3. Modele ujawniają nieprzewidziane właściwości. Fakt, że zewnętrzny model jest bytem niezależnym od swojego autora, oznacza również, że ludzie mogą posługiwać się nim w sposób niezależny od intencji twórcy. Gdy struktura zostaje upubliczniona, zaczyna żyć własnym życiem. W szczególności dotyczy to przedmiotów wieloznacznych. Spójrz na rysunek 7a. Autor być może zamierzał narysować wypukły sześcian, którego dolną i jedną z tylnych ścian przedłużono w prawą dolną stronę. Jednak osoba przyglądająca się temu rysunkowi może początkowo uznać, że te przedłużone ściany to elementy sześcianu stojącego na jednym ze swoich rogów i zwróconego drugim rogiem w stronę patrzącego. Jeśli przyjrzymy się obrazowi nieco dłużej, prawdopodobnie dojdziemy do jeszcze innych interpretacji. Badania nad wyobraźnią wizualną pokazują, że osoby, które podczas tworzenia obrazu w głowie nie odkryły jeszcze wieloznaczności kształtu, najprawdopodobniej nie odkryją jej, analizując ów obraz stworzony w wyobraźni (Chambers i Reisberg 1985). To tak jakby posługiwały się wyjściową koncepcją dla utrzymania wyobrażenia. W ten sposób zamykają się na nowe interpretacje. Jednak gdy mają przed oczami uzewnętrzniony obraz, wówczas sam proces wzrokowy - przy spojrzeniu wędrującym po kształcie w poszukiwaniu spójności - zazwyczaj doprowadzi do odkrycia wieloznaczności ${ }^{31}$. Gdy struktura zostaje głębiej zbadana, wówczas związki i interakcje części, których tu się zupełnie nie spodziewaliśmy, stają się łatwiejsze do odkrycia. W ten sposób sam autor może dojść do interpretacji stworzonego kształtu, których sam nie brał pod uwagę. Bez względu na to, czy uzewnętrzniona rzecz stanowi reprezentację myśli, obrazu czy umysłowej animacji, jej trwałość i niezależność sprawiają, że można rozpatrywać ją w nowym świetle i manipulować nią na nowe sposoby.

Zalety modelowania to osobny temat. Kolejną szczególną właściwość, która jest oczywista w przypadku symulacji matematycznych, stanowi kontrolowana przez użytkownika możliwość uruchamiania i cofania zmian w modelu. Tego typu symulacje oferują trwałość i niezależność od idei autora, gdyż można je uruchamiać, odtwarzać w zwolnionym tempie, zatrzymywać i analizować klatka po klatce. Każdy model normalnych rozmiarów wspomaga nasze interakcje fizyczne. Możemy przekładać go w sposób, który ujawnia perspektywy i powiązania trudno dostrzegalne w innej sytuacji. Kiedy nasza interakcja poddana jest precyzyjnej kontroli lub rozpatrywana jako ruch wzdłuż osi czasu, możemy zestawiać ze sobą migawki w celu dokonywania porównań, co byłoby niemożliwe w innych warunkach. Gdyby nie stabilność, reproduko-

\footnotetext{
${ }^{31}$ Argument ten odnosi się do przetwarzania wzrokowego, jednak stosuje się w równym stopniu do interakcji fizycznych [takich jak manualne], w jakie możemy wejść z fizycznym obiektem.
} 
walność i trwałość, pewne nasze idee dotyczące czasowej dynamiki struktur byłyby po prostu nie do pomyślenia (zobacz rysunek 8a,b).

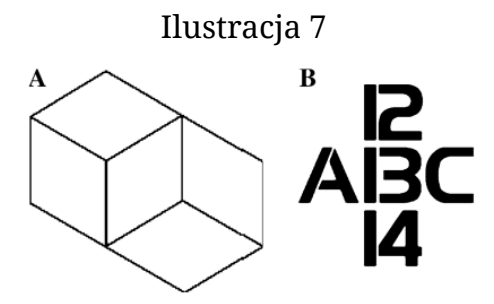

Oto przykłady przedmiotów wieloznacznych. Rysunek $a$ to wariant sześcianu Neckera; jego wierzchołki raz wyglądają na wypukłe, a innym razem jawią się jako wklęsłe. Z rysunkiem $a$ wiąże się kilka interpretacji. Czy dostrzegamy przynajmniej cztery $\mathrm{z}$ nich? Na rysunku $b$ środkowy element jawi się raz jako $B$, a raz jako 13 w zależności od tego, czy czytamy horyzontalnie, czy wertykalnie. To, jak prezentuje się nam przedmiot, zależy od tego, jak na niego patrzymy, a to może zależeć od sposobu prezentacji, kontekstu, naszych odczuć lub tego, jak był prymowany.

Ilustracja 8
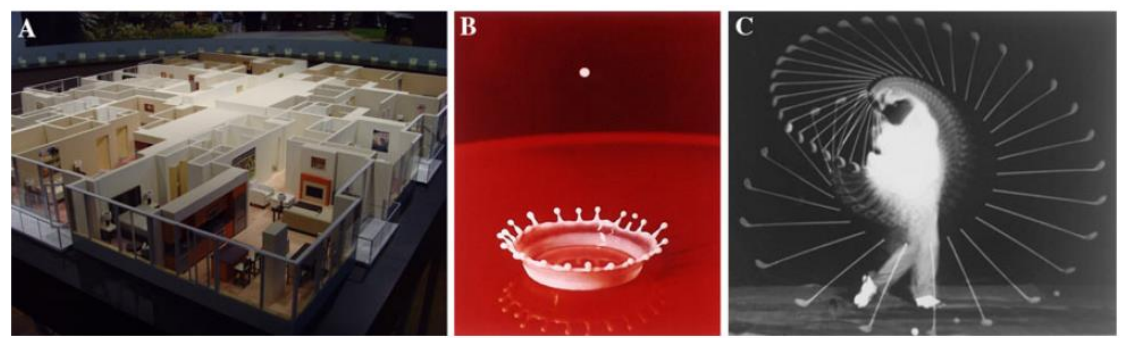

Model trójwymiarowy (a) pozwala architektom na ogląd bryły pod dowolnymi kątami. Umożliwia im pomiary, porównywanie oraz identyfikację ewentualnych naruszeń ograniczeń [projektowych]. Podchodząc do modelu pod przedziwnymi kątami, mogą oni ujrzeć niedrożności i związki, które byłyby trudno dostrzegalne w innej sytuacji. $\mathrm{Na}$ rysunku $b$ widać niemal doskonałą koronkę uformowaną przez rozbijającą się o powierzchnię kroplę mleka, którą uchwycił sławny fotograf Harold Edgerton. Na rysunku $c$ widzimy popularny obraz stopklatek ruchów golfisty uderzającego piłkę kijem. (Przeformułowanie nie ogranicza się wyłącznie do dziedziny rozwiązywania problemów formalnych. Anglojęzyczną wypowiedź „Police police police police police” łatwiej zrozumieć, gdy ujmie się ją w taki oto sposób: „Police who are policed by police, also police other police”. Większość użytkowników języka angielskiego nie trudziłaby się zapisywaniem tego zdania, by je zrozumieć, ale zaledwie kilku z nich potrafi pojąć jego znaczenie bez powtórzenia go na głos kilka razy) (Densmore Shute Bends the Shaft 1938 (c) Dr Harold Edgerton Silver Gelatin Print).

\section{Przeformułowywanie i wyrazistość}

Czwarte ze źródeł siły interakcji wiąże się z naszą umiejętnością zewnętrznego przeformułowywania idei. Niekiedy łatwiej jest formułować na nowo idee na zewnątrz niż w umyśle. Reprezentacje kodują informacje. Niektóre formy kodują informację w sposób bardziej wyrazisty niż inne (Kirsh 1992). Na przykład zarówno zapis „ $\sqrt{2209}$ ”, jak i „47” odnoszą się do liczby 47 , jednak 
drugi z nich jest bardziej wyrazistym sposobem kodowania. Znaczną część działań realizowanych na zewnątrz można interpretować jako przekształcanie wyrażeń do bardziej czytelnych postaci, co ułatwia poznawcze „uchwycenie” treści, którą one kodują. Jest to jedna z ważniejszych metod rozwiązywania problemów. Na przykład zadanie $x=\sqrt[4]{28,561}+\sqrt{2209}$ okazuje się trywialne, gdy pod $\sqrt[4]{28,561}$ oraz $\sqrt{2209}$ podstawimy odpowiednie wartości, tak jak tutaj: $x=13+47^{32}$.

Znaczną część procesów poznawczych można rozpatrywać jako odmianę zewnętrznych działań epistemicznych. Jeśli to stwierdzenie zbyt mocno wiąże się z teorią umysłu rozszerzonego (Clark 2008), można dodać tutaj słowo „zarządzanie” - i otrzymać wypowiedź w rodzaju: „Znaczna część procesów poznawczych zakłada zarządzanie zewnętrznymi działaniami epistemicznymi”. Przeformułowujemy i podmieniamy reprezentacje, zmierzając do tego, by treść była bardziej wyrazista. Tak długo opracowujemy problemy, aż rozwiązania stają oczywiste.

Jedną z bardziej przydatnych rzeczy, które robimy poza naszymi głowami, jest przeformułowywanie reprezentacji zewnętrznych tak długo, aż te będą kodowały treść w sposób bardziej przejrzysty, bardziej wyrazisty. Ale dlaczego trudzimy się? Dlaczego nie przekształcimy reprezentacji wewnętrznie? Powodem, by dokonywać obliczeń na zewnątrz, jest to, że pracując w ten sposób, możemy skorzystać z powszechnie dostępnych algorytmów oraz specjalnych artefaktów służących kodowaniu i obliczaniu. Struktura kosztów procesów obliczeniowych jest zdecydowanie odmienna dla działania wewnątrz i na zewnątrz. Spróbuj wyliczyć w głowie $\sqrt{2209}$ bez posługiwania się kalkulatorem lub algorytmem. Nawet sawanci, którzy rozwiązują to zadanie poprzez „po prostu myślenie”, mają swoje ograniczenia. Ostatecznie bez względu na to, kim jesteśmy, problemy staną się zbyt duże lub złożone, by rozwiązać je w głowie. Zadania tego typu stają się wykonalne dzięki zewnętrznym algorytmom, które oferują mechanizmy manipulacji symbolami zewnętrznymi. W istocie, gdyby rozpisać obliczeniowe profile kosztów (wyrażone w kategoriach stosunku szybkości do precyzji) dla obliczeń typu dodawania liczb w głowie w zestawieniu z posługiwaniem się algorytmami lub otaczającymi nas narzędziami, stanie się jasne, dlaczego większość młodych ludzi nie przeprowadza już operacji arytmetycznych w swoich głowach. Narzędzia zmieniają strukturę kosztów wykonywania zdań, a ludzie dostosowują się do tego, uzależniając się od swoich narzędzi.

\footnotetext{
${ }^{32}$ Chcąc zrozumieć, jak to możliwe, że muzyka może być jednocześnie desygnatem i reprezentacją (terenem, a jednocześnie jego mapą), zastanówmy się na tym, czy istnieje różnica między słuchaniem [po prostu] dźwięków a słuchaniem dźwięków jako muzyki. Dźwięk jest niczym teren; muzyka jest konceptualizującą strukturą, która stanowi interpretację dźwięku; mapuje go.
} 
Drugi powód, dla którego obliczamy raczej na zewnątrz niż wewnątrz, związany jest $\mathrm{z}$ różnymi rodzajami złożoności. Jedna z metod przeformułowania zakłada podmienianie i przepisywanie. Na przykład jeśli mamy ustalić wartość $x$, wiedząc, że $x^{2}+6 x=7$, łatwiej nam będzie, jeżeli lewą stronę równania zastąpimy wyrażeniem $(x+3)^{2}-9$. Jest to sprytna sztuczka wymagająca spostrzegawczości. Trzeba zauważyć, że $(x+3)^{2}=x^{2}+6 x+9$, co jest bardzo bliskie $x^{2}+6 x=7$. Dokonując podmiany, uzyskujemy równanie $(x+3)^{2}=16$, co daje $x$ $=1$ lub -7 . Czy tego typu podmianę można by przeprowadzić $\mathrm{w}$ pamięci? Raczej nie. Nawet jeśli są ludzie do tego zdolni, tak jak było w przypadku wyciągania pierwiastków, zawsze będzie jakaś granica, za którą wymagane podmiany stają się zbyt złożone, by można było przewidywać ich efekty, „po prostu myśląc” o tym wewnątrz głowy. Nowe sformułowania równań należy włączyć do świata zewnętrznego, podobnie jak w sytuacji, gdy wymieniamy starą część na nową i odpalamy naprawiany silnik, by sprawdzić, czy wszystko prawidłowo działa. Gdybyśmy nie sprawdzali rzeczy w świecie fizycznym, przewidywania konsekwencji wprowadzanych zmian byłyby zbyt trudne i w zbyt dużym stopniu narażone na błędy. Zawsze możliwe są interakcje oraz efekty uboczne. To samo dotyczy zasad rządzących przeformułowywaniem, które zakładają określone zasady przekształceń. Rewizje i interakcje szybko stają się na tyle złożone, że nie sposób oczekiwać od ludzi, by wykrywali je lub zapamiętywali.

\section{Naturalne kodowanie}

Trwałość, reorganizacja oraz przeformułowywanie w dużej mierze tłumaczą, w jaki sposób eksternalizacja informacji i reprezentacji może przekładać się na wzrost sprawności, precyzji, złożoności i głębi poznania. Jeśli te aspekty interakcji z reprezentacjami zewnętrznymi nie wyjaśniają dodatkowych mocy [poznawczych], to z pewnością wyjaśnia je zjawisko symulacji. Wciąż jednak pozostaje inna kwestia, którą należy wziąć pod uwagę: w jaki sposób reprezentacje zewnętrzne mogą zwiększać zakres poznania. Aby zgłębić to zagadnienie, rozpatrzymy ponownie, dlaczego $\mathrm{w}$ przypadku określonych typów myślenia bardziej preferujemy pewne modalności.

Każdy system reprezentacji czy modalność ma swoje mocne i słabe strony. Wywód lub atrybucja uznawana za oczywistą w obrębie jednego systemu może nie być już taka w obrębie innego. Rozpatrzmy przykład zaprezentowany na rysunku 9, który dotyczy zapisu nutowego. Desygnatem notacji jest fragment utworu muzycznego. Muzyka to [zestaw] dźwięków o określonej tonacji lub harmonii, głośności, tembrze i dynamice czasowej. A zatem „naturalną” domeną muzyki jest modalność dźwiękowa. Wizualny zapis muzyki nabudowany jest na strukturze dźwięku. Na pierwszy rzut oka najlepszą reprezentacją sensu struktur muzycznych wydaje się sama muzyka; zwracamy się do źródła, by zrozumieć jego strukturę (zob. przypis 2). 
Ilustracja 9

A

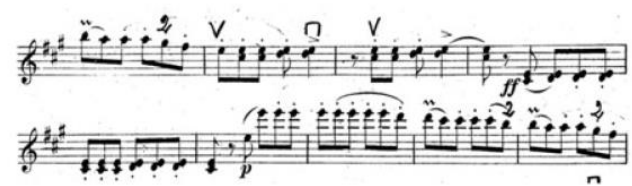

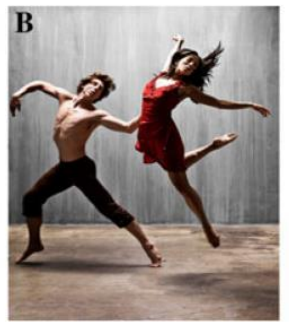

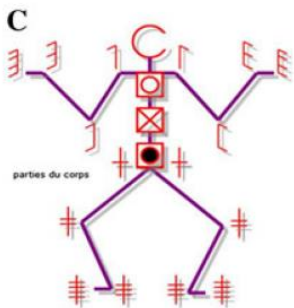

Wyobraźmy sobie, że odsłuchujemy 12 sekund muzyki. Spójrzmy teraz na powyższy zapis nutowy. Zapis ma tę zaletę, że ukazuje w postaci przestrzennej to, co słyszymy. Jednak dźwięk muzyki zawiera dużo więcej niż to oddaje sam zapis. Dźwięk to naturalna reprezentacja muzyki. To samo dotyczy tańca. Porównajmy zapis Labana z wykonaniem przez tancerza całej struktury tanecznej. Nawet jeśli zapis prawidłowo oddaje zgięcia stawów, to na ile dobrze reprezentuje dynamikę ruchu, odczucie tańca czy jego estetykę?

Skoro istnieją przypadki, w których źródłowe medium jest konieczne do zaprezentowania treści myśli, to kolejnym powodem, by eksternalizować treści i manipulować nimi poza umysłem, jest sytuacja, kiedy naturalna reprezentacja treści pewnych problemów istnieje tylko na zewnątrz. Możemy przyjąć, że nikt - lub w najlepszym przypadku bardzo niewielu - nie słyszy muzyki w swojej głowie tak jak słyszy ją na zewnątrz. Umysłowe obrazy dźwięku mają inne właściwości niż same dźwięki. Nawet jeśli możliwe jest doznawanie wyobrażeń muzyki, które będzie równie żywe i szczegółowe jak doznawanie jej w rzeczywistości, to tylko nieliczni - pomijając muzycznie uzdolnionych, zawodowych muzyków oraz kompozytorów (Sacks 2008) - mogą precyzyjnie kontrolować muzyczne reprezentacje w swoich głowach. Zdecydowanie łatwiej jest prezentować muzykę na zewnątrz niż w umyśle. W związku z tym wielu ludzi, chcąc pojąć jakąś muzykę, zaczyna od jej odsłuchania lub odegrania.

To odnosi nas do kolejnych wymogów, jakie musi spełniać rzecz, by mogła stać się elementem procesu myślowego. Jeśli system reprezentacyjny ma pełnić funkcje medium myśli, poszczególne jego elementy muszą być łatwe w manipulacji, by można było sprawnie nim się posługiwać. Słowo pisane i mówione jest plastyczne i szybkie. Podobnie jest z ruchami ciała w tańcu, gestami; być może to jest tak jak z podatnością gliny. Podobnie instrumenty muzyczne umożliwiają szybkie wytwarzanie dźwięków. Te zewnętrzne media lub narzędzia służące tworzeniu mediów umożliwiają sprawną pracę. Pozwalają nam pracować z plastycznymi mediami. Pod tym względem sprawiają, że możemy działać na zewnątrz w sposób podobny do tego wewnątrz, posługując się widzialnymi i słyszalnymi reprezentacjami w miejsce słów i idei, którymi większość z nas posługuje się z szybkością myśli. Jeśli manipulowalność 
zewnętrznego [medium] spełnia nasze wewnętrzne wymogi dotyczące szybkości, wówczas medium to posiada plastyczność wystarczającą, by przydać się w myśleniu.

\section{Posługiwanie się reprezentacjami wielotorowymi}

Pomijając korzyści płynące ze słuchania muzyki, zdarza się, że notacja ujawnia więcej niż dźwięki, które słyszymy; przykładem jest sytuacja, w której nienaturalna dla nas reprezentacja może być dla nas bardziej odkrywcza i intuicyjna niż reprezentacja oryginalna. Z uwagi na fakt, że zapis nutowy jest trwały i obszerny w sensie przestrzennym, wcześniejsze i późniejsze struktury [dźwiękowe składające się na utwór] mogą być ze sobą porównywane, nakładane na siebie oraz przekształcane za pomocą specjalnych operatorów. Podobnie jak w przypadku puzzli i [dowodów] logicznych, opłaca się mieć namacalną reprezentację, którą możemy manipulować. W tym konkretnym przypadku osoba przełączająca się między dwiema reprezentacjami może rozszerzyć swoje możliwości poznawcze. Przełączając się między słuchaniem muzyki, zapisywaniem utworu w postaci partytury oraz słuchaniem i następnie odczytywaniem zapisu, a czasami na odwrót, kompozytor lub słuchacz może odkryć takie właściwości struktury muzycznej, które byłyby dla niego niedostępne w innym trybie. Im bardziej złożona jest struktura utworu, tym bardziej wydaje się to prawdziwe. Bez korzystania z reprezentacji wielotorowych pewne odkrycia pozostałyby po prostu poza naszym zasięgiem. Z podobnym zjawiskiem mają do czynienia projektanci, którzy posługują się na zmianę papierowymi szkicami, trójwymiarowymi makietami oraz prostymi prototypami.

\section{Konstruowanie i narzędzia}

Ostatnia z zalet interakcji zewnętrznych, która tutaj omówimy, jest w pewnym sensie połączeniem trwałości, reorganizacji i przeformułowań. Zaletę te można określić jako możliwość konstruowania. W tworzeniu konstrukcji - bez względu na to, czy chodzi o naniesienie graficznych adnotacji dotyczących tańca widocznych na rysunku 5, wykreślenie geometrycznego kształtu widocznego na rysunku 1, czy o skonstruowanie prototypu przedstawionego na rysunku 8a - tkwi coś magicznego, związanego ze stwarzaniem czegoś w świecie. Jak już wspomnieliśmy w kontekście omawiania zeskalowanych modeli, poprzez realizowanie konstrukcji dowodzimy, że jej poszczególne części są wzajemnie spójne. Jeśli da się coś zbudować, oznacza to, że rzecz ta jest logicznie i fizycznie sensowna. Jeśli da się coś uruchomić, to znaczy, że części konstrukcji spójnie pracują ze sobą, przynajmniej na ogół, a jeśli uda nam się uruchomić dany układ w różnych warunkach, oznaczać to będzie, że system będzie zawsze spójny. Fizyczny świat nie kłamie. 
Proces konstruowania ma specjalne znaczenie dla ludzkiego myślenia, gdyż jest samo-uwierzytelniajacy. $\mathrm{W}$ matematyce rozumowanie konstrukcyjne oznacza dowiedzenie istnienia danego konstruktu matematycznego poprzez pokazanie go. Na przykład jeśli twierdzilibyśmy, że dany zbiór ma największy element, konstrukcjonistycznym dowodem byłoby wskazanie metody odnajdywania największego z elementów, a następnie zastosowanie jej do wskazania tego elementu.

Nie każda odmiana ludzkiego rozumowania jest konstruktywna. Ludzie wnioskują na zasadzie analogii, indukcji, formułują wyjaśnienia, myślą, wykonując inne czynności, takie jak postępowanie zgodne z instrukcjami, odczytywanie obcego języka i tak dalej. Żadna z tych form rozumowania nie jest konstrukcyjna w matematycznym tego słowa znaczeniu. Jednakże z uwagi na przyrostowy charakter konstrukcji próby stworzenia rozwiązania mogą również stanowić sposób na zrozumienie problemu. Kiedy uczniowie poszukują konstrukcjonistycznego dowodu odnośnie do problemu z zakresu geometrii, posługują się ewoluującą strukturą zewnętrzną, by stymulować u siebie pojawianie się idei, przypadkiem odkrywać ograniczenia nałożone na układ oraz uświadamiać sobie istniejące możliwości. Lub też gdy zapiszą już przekład części danego tekstu, wspomagają się zrozumiałymi fragmentami w toku dalszego tłumaczenia.

Należy zadać tu sobie pytanie, czy myślenie za pomocą elementów zewnętrznych jest zawsze konieczne. Czy zasadniczo moglibyśmy robić wszystko $\mathrm{w}$ naszych głowach, czy może musimy wchodzić $\mathrm{w}$ interakcje z rzeczami zewnętrznymi względem nas, aby poznawać właściwości, konceptualizować i rozwiązywać problemy? W matematyce eksternalizacja jest niezbędna nie tylko na potrzeby komunikacji, ale także w celu demonstrowania przedmiotu matematycznego, którego dotyczy problem. To jak z pomiarem: nie możemy podać wielkości danego parametru fizycznego, nie dokonując pomiarów. Nie możemy udowodnić realności danego przedmiotu matematycznego (przynajmniej nie matematycznemu konstruktywiście) bez przeprowadzenia dowodu, który demonstruje dany przedmiot. Czy jednak na etapie odkrywania całe myślenie nie może przebiegać wewnątrz, być rezultatem interakcji między elementami wewnątrz naszych głów? Gdzie dowód, że wszystkie te badania i konceptualizacje nie stanowią wyniku procesów czysto wewnętrznych? Czy nie jest tak, że „prawdziwe” myślenie rozgrywa się wewnątrz i że wewnętrznie symulujemy i sprawdzamy rzeczy, jeszcze zanim je opiszemy na zewnątrz? A może wewnętrzna aktywność uzewnętrznia się tylko po to, by najwłaściwiej zaprezentować własne wewnętrzne idee innym? Wreszcie może jest tak, że świata zewnętrznego potrzebujemy na etapie uczenia się myślenia $^{33}$, jednak gdy kończymy naukę, nie potrzebujemy już więcej fizycznych,

${ }^{33}$ Lew Wygotski oraz inni badacze sugerowali, że umiejętność myślenia opanowujemy na zewnątrz, poprzez podporządkowywanie naszego zachowania społecznym normom racjonalnego 
namacalnych, dwu- czy trójwymiarowych struktur jako poznawczych narzędzi służących zgłębieniu rzeczywistości?

Sądzę, że takie podejście jest błędne: fizyczna interakcja z namacalnymi elementami stanowi konieczną część procesu myślowego, gdyż są sytuacje, gdy formułując pewne myśli i przechodząc między nimi, musimy zdać się na procesy fizyczne. Istnieją pewne akty poznawcze, które możemy zrealizować poza naszymi głowami, a których po prostu nie potrafimy wykonać wewnątrz. W takich sytuacjach procesy zewnętrzne działają na zasadzie specjalnego rodzaju artefaktów poznawczych (Hutchins 2001), których nie jesteśmy w stanie symulować $\mathrm{w}$ umyśle.

Obrona owej hipotezy jest trudniejsza niż mogłoby się zdawać. W praktyce tylko nieliczne osoby potrafią $\mathrm{w}$ głowie pomnożyć przez siebie dwie czterocyfrowe liczby. Nawet gdyby było inaczej, moglibyśmy zawsze podwyższyć trudność i polecić pomnożyć przez siebie liczby dziesięciocyfrowe. Jednak istnienie tego typu ograniczeń „w praktyce” nie dowodzi twierdzenia, że „w zasadzie” mózg normalnego człowieka nie jest zdolny rozwiązać pewnych problemów, które można rozwiązać, korzystając z pomocy zewnętrznej, za pomocą narzędzi, komputerów czy innych osób. Istnieją mistrzowie szachowi, którzy potrafią grać niemal tak samo dobrze z zasłoniętymi oczami, jak i z otwartymi (Chabris i Hearst 2003) ${ }^{34}$. Nie ma dowodu na to, że zespół szachistów jest lepszy niż pojedynczy gracz ${ }^{35}$. Istnieją sawanci, którzy potrafią mnożyć przez siebie duże liczby, określać, czy dana liczba jest liczbą pierwszą, wyciągać pierwiastek kwadratowy. Innego typu sawanci, obdarzeni pamięcią ejdetyczną, potrafią czytać książkę z szybkością jednej strony na 8-10 sekund, zapamiętując niemal wszystko (zob. przypis 5). Nikola Tesla powiadał, że gdy projektuje jakieś urządzenie, symuluje przez kilka tygodni pracę układu, by

dociekania, a to, co najpierw opanujemy na zewnątrz, możemy następnie wykonać wewnętrznie. A zatem powodem, dla którego potrafimy wykonywać operacje matematyczne w głowie, byłoby to, że potrafimy to samo robić w świecie. To samo stosuje się do wewnętrznego procesu myślenia za pomocą wyobraźni słuchowej. Myślimy wewnątrz za pomocą słów, korzystając ze słuchowych obrazów dźwięku, gdyż podczas myślenia publicznie mówimy. Myślenie wewnętrzne byłoby symulacją tego, co robimy na zewnątrz, jednak sam Wygotski uważał, że wewnętrzna mowa dorosłych byłaby mocno skompresowana i niezrozumiała dla kogokolwiek poza jej użytkownikiem (Wygotski 1986).

${ }^{34}$ Warto tutaj przytoczyć fragment wpisu z angielskiej Wikipedii na temat Kima Peeka, który zainspirował postać tytułowego bohatera filmu Rain Man: „Czytał książkę mniej więcej w godzinę i pamięta niemal wszystko. (...) Jego technika polegała na tym, że czytał dwie strony naraz, jedną jednym okiem, a drugą drugim; przeczytanie dwóch stron zajmowało mu 8-10 sekund. Znał na pamięć treść 12000 książek".

${ }^{35}$ Coś takiego jak zespołowa gra w szachy praktycznie nie istnieje, więc jak na razie twierdzenie, że drużyny nie są lepsze od pojedynczych graczy, opiera się obecnie na tym, że szachiści unikają grania zespołowego. Wartym odnotowania wyjątkiem jest Alexander Alekhine, który zmierzył się z 28 czteroosobowymi drużynami szachowymi, wygrywając 22 razy, remisując trzy razy i przegrywając trzy razy. 
stwierdzić, które elementy są najbardziej narażone na zużycie (Hegarty 2004: 281, za Shepherdem). Twierdzi się, że Stephen Hawking rozwinął swoje umiejętności analityczne $\mathrm{w}$ takim stopniu, że potrafi manipulować $\mathrm{w}$ swoim umyśle równaniami odpowiadającymi przeszło stronie ręcznie spisanych ciągów. Skąd możemy wiedzieć, czy dla dowolnego problemu poznawczego o złożoności $n$ nie istnieje gdzieś jakaś osoba, która może rozwiązać go w swojej głowie lub mogłaby, gdyby została do tego odpowiednio przeszkolona? Oczywiście niewiele mówi nam to o przeciętnym człowieku. Większość osób osiągnie granice swoich możliwości, próbując poradzić sobie z problemem o poziomie złożoności zdecydowanie niższym niż $n$. Nasza technologia i kultura ewoluowały $\mathrm{w}$ taki sposób, by zapewnić wsparcie dla większości ludzi. A zatem w praktyce większość ta polega na dostępnych jej narzędziach, metodach i technikach [wspomagających] rozumowanie. Niemniej jednak jeśli pojedyncza osoba jest w stanie poradzić sobie $\mathrm{z} n$, dowodzi to, że złożoność symulacji zewnętrznych nie zaprzecza jeszcze możliwości symulacji wewnętrznych. A to oznacza, że problem, którego nie możemy rozwiązać w naszych głowach, a z którym radzimy sobie z pomocą zewnętrzną, ma więcej wspólnego ze strukturą kosztów niż z zakładanymi naszymi ograniczeniami natury biologicznej.

Jednym ze sposobów dowiedzenia słuszności mojej hipotezy jest wskazanie operacji, które można przeprowadzić na reprezentacjach zewnętrznych, ale już nie na wewnętrznych, i wykazanie, że mają one istotny charakter. Czy istnieją zatem takie zabiegi epistemiczne, które możemy przeprowadzić na zewnątrz, a nie możemy powtórzyć ich wewnątrz nie ze względu na ich złożoność, lecz dlatego, że istnieją w świecie pewne właściwości i technologie, których nie jesteśmy w stanie skopiować w umyśle: operacje, których nie jesteśmy w stanie zasymulować myślowo w sposób na tyle realistyczny, by dostarczały nam niezawodnych odpowiedzi?

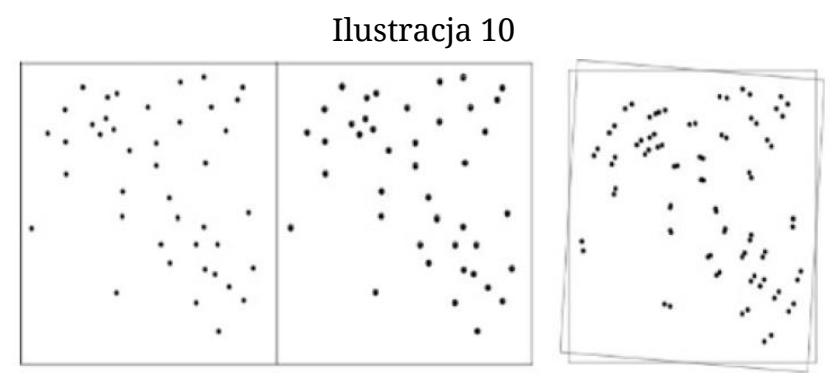

Po lewej stronie mamy dwa układy kropek. Jedyna różnica między nimi polega na tym, że drugi układ został obrócony o 4 stopnie w prawo. Po stronie prawej oba układy zostały nałożone na siebie. Dopiero dzięki temu widać relację między nimi. Czy związek ten można by ustalić bez fizycznego nałożenia na siebie wzorców? Nasze umiejętności wewnętrznego wyobrażania sobie obrazów nie obejmują tak szczegółowego nakładania ich. Nawet jeśli istnieją ludzie obdarzeni tak specyficzną umiejętnością, nieuchronnie zawiedzie ich ona wraz ze wzrostem liczby kropek lub nakładanych obrazów. 
Rozważmy rysunek 10 . Kropki na obu obrazkach są powiązane ze sobą na takiej zasadzie, że te na drugim obrazku stanowią efekt odwrócenia obrazka o cztery stopnie. Nie sposób tego dostrzec, chyba że oba obrazki zostaną na siebie nałożone, tak jak na obrazku po prawej. Nałożenie to fizyczna czynność, którą można powtórzyć dowolną liczbę razy, podobnie jak rotację. Obie wymagają sprawowania kontroli nad fizycznymi przekształceniami. W przypadku nałożenia obrazków musimy kontrolować położenie płaszczyzn, a w przypadku rotacji - kąt. Czy takie funkcje posiada również mózg?

Procesy mózgowe niezbędne do wykonania tego zadania musiałyby mieć charakter analogowy. Przez 25 lat toczył się spór o to, czy w mózgu możliwe są procesy analogowe, oraz wokół tego, czy wyobraźnia wizualna działa w oparciu o czynniki nie-analogowe (Pylyshyn 2001). Możemy uniknąć tego problemu przez odwołanie się do zasadniczego rozróżnienia między rodzajami procesów. W ważnym artykule John Von Neumann (1948) zauważył, że niektóre procesy naturalne mogą być nieredukowalnie złożone. Dowolny opis takiego procesu byłby równie złożony co sam proces. Chcąc zasymulować ów proces, trzeba by odtworzyć wszystkie składające się na niego czynniki.

Takie stwierdzenie odnosi się również do sytuacji, gdy symulacja bądź modelowanie jest wykonywane wewnętrznie lub zewnętrznie. Jak stwierdził von Neumann,

nie ma pewności, czy w tym zakresie realny obiekt nie mógłby stanowić jednocześnie najprostszego własnego opisu. Tym samym próby opisania danego obiektu za pomocą zwykle wykorzystywanych metod formalnologicznych mogłyby doprowadzić do wykształcenia przedstawień trudniejszych w obsłudze i bardziej skomplikowanych (311).

David Marr, wypowiadając się na ten sam temat, mówił o procesach typu 2, w których jakakolwiek abstrakcja byłaby złudna, ponieważ opisywane zjawisko zmienia się w wyniku ,jednoczesnego zachodzenia licznych procesów, a interakcje zachodzące między poszczególnymi procesami są ich najprostszym opisem” (Marr 1977: 37-48). Zdaniem Marra ${ }^{36}$ łączenie się i rozpad łańcuchów białkowych to właśnie jeden $\mathrm{z}$ takich procesów. Innymi przykładami mogą być: problem ciała $n$, rozwiązania niektórych problemów dotyczących rów-

\footnotetext{
${ }^{36}$ Jak pisze Marr (1977: 38) „Jednym z kandydatów na teorię typu 2 jest problem przewidywania, w jaki sposób zwijają się białka. Na łańcuch polipeptydowy oddziałuje wiele czynników, gdy ten trzepocze i zgina się $\mathrm{w}$ swoim ośrodku. $\mathrm{W}$ danej chwili znaczenie ma jedynie kilka $\mathrm{z}$ wielu możliwych interakcji, jednak ich wpływ jest decydujący [dla efektu końcowego]. Próby opracowania uproszczonej teorii muszą pominąć część interakcji, jeśli jednak ich większość jest istotna na którymś etapie zwijania, to uproszczona teoria zawiedzie. Co ciekawe, obecnie najbardziej obiecujące badania nad zwijaniem się białek to te, które zakładają udział brutalnej siły, począwszy od szczegółowego modelu aminokwasów, geometrii wynikającej z ich sekwencji, interakcji hydrofobowych z płynami otaczającymi, przypadkowych perturbacji termicznych itd. oraz [symulowania] procesu zwijania, aż do momentu uzyskania stabilnej konfiguracji (Levitt i Warshel 1975)”.
} 
nowagi rynkowej, sytuacje zależne od wyniku głosowania uczestniczących w nich $n$ osób oraz niektóre obliczenia kwantowe.

Cechą wyróżniającą wspomniane sytuacje jest zachodzenie procesów fizycznych rozpoczynających i kończących się stanami, które podlegają interpretacji, ale sam ich przebieg jest nieprzewidywalny. Wiele czynników naraz kształtuje koniec i początek takich procesów, dlatego też nie da się przewidzieć ich rezultatów, badając każdy z czynników osobno. Aby określić rezultat konkretnego procesu, należy obserwować dane zjawisko w praktyce, najlepiej wielokrotnie. Żadne możliwe do rozwiązania równanie nie ma zastosowania w opisanych przypadkach.

Jak mamy rozwiązać tego typu problemy, nie posiadając dostępu do tych procesów czy do samego systemu? Skoro nie mamy dostępu do rzeczywistego zjawiska, możemy wywołać proces zbliżony pod względem fizycznym. Na przykład najlepszym sposobem wyliczenia zachowania układu ciał takiego jak nasz układ słoneczny jest skonstruowanie pomniejszonego, analogowego modelu systemu - mechanicznego planetarium [orrery] - a następnie wprawienie go w ruch i odczytanie uzyskanych rezultatów (zob. rysunek 11). Posługując się procesami analogowymi, możemy wyliczyć funkcję (przy zadowalającym stopniu przybliżenia), której nie bylibyśmy w stanie poprawnie wyznaczyć w jakikolwiek inny sposób.

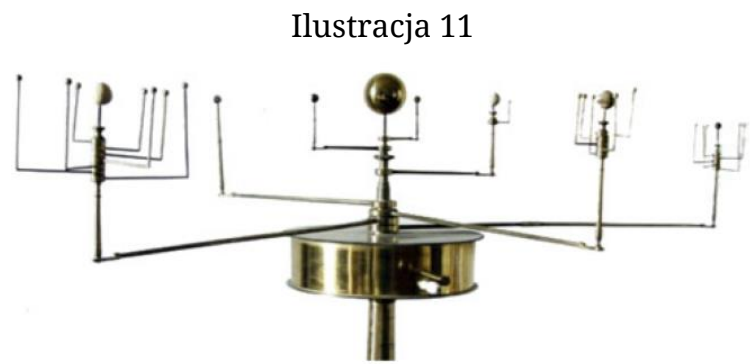

To mechaniczne planetarium wykonane przez Gilkerson and Co., które przechowywane jest w Armagh Observatory, mechanicznie symuluje ruch planet i ich satelitów. Nie możemy przejść od razu do dowolnego stanu systemu, tylko musimy przemieścić się przez wszystkie pośrednie stany od momentu uruchomienia symulacji. To jest wyróżnik systemów symulacyjnych: nie mają domkniętej formy ani analitycznego rozwiązania. By wyliczyć stan systemu $t_{12}$, należy najpierw określić stan $t_{11}$ i od niego rozpocząć.

Wniosek jest taki, że mózg, który miałby rozwiązać tego typu problem, musiałby zakodować wyjściowy stan układu drugiego typu, a następnie przeprowadzić symulację interakcji poszczególnych elementów układu. Gdyby interakcje te miały charakter fizyczny - na przykład gdyby bazowały na fizycznych stanach równowagi, podatności czy tarciu - okazać by się mogło, że nie ma żadnego niezawodnego sposobu przeprowadzenia takiej symulacji w 
umyśle. Konieczne okazuje się skorzystanie ze wspomagania poznawczego, jakie oferują modele fizyczne. Musimy polegać na równoległym przetwarzaniu, fizycznej interakcji i nieodłącznej nieprzewidywalności tych analogowych systemów. W naszych mózgach (czy umysłach) nie znajdziemy niczego takiego.

Konkluzja, jaka się tutaj nasuwa, jest taka, że do formułowania pewnych myśli i przechodzenia do innych niezbędna jest umiejętność reprezentowania dowolnie złożonych stanów - takich, których nie można zaprezentować w formie uproszczonej - lub też poleganie na tych właśnie zewnętrznych stanach w celu zakodowania ich samych i posłużenia się nimi w celu przejść do stanów kolejnych. Możemy nazwać te zewnętrzne stany, ale nigdy nie będziemy umieli dokonać ich pełnej charakterystyki strukturalnej ${ }^{37}$.

\section{Podsumowanie}

W celu wydobywania znaczeń, wyciągania wniosków oraz - ogólnie rzecz ujmując - pogłębienia naszego rozumienia świata często markujemy, posługujemy się adnotacjami, tworzymy reprezentacje; zmieniamy ich porządek, nadbudowujemy nad nimi, przerabiamy je, zestawiamy oraz wykonujemy wiele innych manipulacji. Dlaczego się trudzimy? Umysły to mocne urządzenia służące do rzutowania struktur na świat oraz wyobrażania sobie ich, gdy struktura jest nieobecna. Nasza wewnętrzne życie umysłowe jest plastyczne, podatne na kontrolę, wypełnione fragmentami wypowiedzi, wizualnymi scenami i bezobrazowymi sądami. Przez większość czasu ten niesamowity zasób możliwości uznawano za wystarczającą bazę dla przebiegu procesów myślowych. Dlaczego zatem tak bardzo trudzimy się wchodzeniem w interakcje?

Jak starałem się dowieść, znaczna część procesów myślowych krąży wokół interakcji z reprezentacjami zewnętrznymi i czasami te interakcje nie dają się sprowadzić do procesów, które dawałyby się symulować, wywoływać i kontrolować w głowie. Często powód, dla którego wchodzimy w interakcje z reprezentacjami zewnętrznymi, sprowadza się do kwestii kosztów. Nie ma niczego za darmo. Przydatnym podejściem do interakcji epistemicznych jest próba ujęcia ich jako środków redukujących koszty projektowania struktur na świat. Rozwiązując problem natury geometrycznej, moglibyśmy wyobrazić sobie strukturę i rozważać ją wewnętrznie; moglibyśmy pracować z użyciem rysunku oraz projektować na niego rozszerzenia i możliwości. Jednak w pew-

\footnotetext{
${ }^{37} \mathrm{~W}$ praktyce, choć nie zawsze, do kategorii tej zaliczają się komputery. Gdy już wzbogacimy nasze stanowisko pracy różnego rodzaju narzędziami typu kreatory, oprogramowanie agentowe i tym podobne, możliwe jest zwielokrotnienie potencjału podstawowych strategii interakcji aż do poziomu jakościowych zmian w zakresie ludzkich możliwości. Niekiedy jednak najlepsze narzędzia mają charakter analogowy i to właśnie one wspomagają ludzki umysł w sposób, który zasadniczo jest możliwy do uzyskania tylko dzięki pomocy z zewnątrz.
} 
nym momencie koszt projektowania staje się zbyt wygórowany. Tworząc zewnętrzne struktury zakotwiczające i wizualnie kodujące nasze projekcje, możemy zajść dalej, obliczać sprawniej, a także tworzyć formy, które pozwalają nam współdzielić myśli z innymi. Omówiłem kilka znaczących konsekwencji zjawiska interakcji. Stanowią one część pewnej bardziej ogólnej strategii, którą rozwinęliśmy jako ludzie, by projektować i urzeczywistniać znaczące struktury.

\section{Literatura}

Baddeley, A.D. 2000. The episodic buffer: a new component of working memory? Trends Cogn Sci 4:417-423.

Chabris, C.F., Hearst, E.S. 2003. Visualization, pattern recognition, and forward search: effects of playing speed and sight of the position on grandmaster chess errors. Cogn Sci 27:637-648.

Chambers, D., Reisberg, D. 1985. Can mental images be ambiguous? J Exp Psychol Hum Percept Perform 11:317-328.

Clark, A. 2008. Supersizing the mind: embodiment, action, and cognitive extension. Oxford University Press, Oxford.

Fauconnier, G., Turner, M. 2002. The way we think: conceptual blending and the mind's hidden complexities. Basic Books, New York.

Forsythe, W. 2008. http://www.youtube.com/watch?v=0P_4D8c2oGs\&feature=related.

Giere, R. 2004. The problem of agency in scientific distributed systems. J Cogn Cult 4(3):759-774.

Hegarty, M. 2004. Mechanical reasoning by mental simulation. Trends Cogn Sci 8:280285.

Hollan, J., Hutchins, E., Kirsh, D. 2000. Distributed cognition: toward a new foundation for human-computer interaction research. ACM Trans Comput Hum Interact 7(2):174-196.

Hutchins, E. 2001. Cognitive artifacts. Wilson, R., Keil F., red. The MIT encyclopedia of the cognitive sciences. MIT Press, Cambridge, MA.

Hutchins, E. 2005. Material anchors for conceptual blends. J Pragmat 37:1555-1577.

Kirsh, D. 1992. When is information explicitly represented? The Vancouver Studies in Cognitive Science. Oxford University Press, Oxford: 340-365.

Kirsh, D. 1995. The intelligent use of space. Artif Intell 73:31-68.

Kirsh, D. 1996. Adapting the environment instead of oneself. Adapt Behav 4:415-452.

Kirsh, D. 2009a. Problem solving and situated cognition. Robbins, P., Aydede, M., red. The Cambridge handbook of situated cognition. Cambridge University Press, Cambridge: 264-306. 
Kirsh, D. 2009b. Projection, problem space and anchoring. Taatgen, N., van Rijn, H., Nerbonne, J., Schomaker, L., red. Proceedings of the 31st annual conference of the cognitive science society. Cognitive Science Society, Austin, TX: 2310-2315.

Kirsh, D. 2009c. Interaction, external representation and sense making. Taatgen, N., van Rijn, H., Nerbonne, J., Schomaker, L., red. Proceedings of the 31st annual conference of the cognitive science society. Cognitive Science Society, Austin, TX: 11031108.

Kirsh, D., Maglio, P. 1994. On distinguishing epistemic from pragmatic actions. Cogn Sci 18:513-549.

Koriat, A., Norman, J. 1984. What is rotated in mental rotation? J Exp Psychol Learn Mem Cogn 10:421-434.

Levitt, M., Warshel, A. 1975. Computer simulation of protein folding. Nature 253:694698.

Logie, R.H. 1995. Visuo-spatial working memory. Lawrence Erlbaum Associates, Hove, UK.

Marr, D. 1977. Artificial intelligence: a personal view. Artif Intell 9:37-48.

Nagel, E., Newman, J. 1958. Gödel’s proof. New York University Press, New York.

Pirolli, P.L. 2007. Information foraging theory: adaptive interaction with information. Oxford University Press, Cambridge.

Pylyshyn, Z. 2001. Is the imagery debate over? If so, what was it about? Dupoux, E., red. Language, brain, and cognitive development: essays in honor of Jacques Mehler. MIT Press, Cambridge, MA: 59-83.

Quine, W.V.O. 1960. Word and object. MIT Press, Cambridge, MA. 1999. Stowo i przedmiot. Tłum. C. Cieśliński. Warszawa: Fundacja Aletheia.

Robbins, P., Aydede, M., red. 2009. The Cambridge handbook of situated cognition. Cambridge University Press, Cambridge: 264-306.

Russell, D.M., Card, S., Pirolli, P., Stefik, M. 1993. The cost structure of sensemaking, Proc CHI 1993.

Sacks, O. 2008. Musicophilia: tales of music and the brain. Alfred A. Knopf, New York / 2009. Muzykofilia. Opowieści o muzyce i mózgu. Tłum. J. Łoziński. Poznań: Zysk i S-ka.

Scaife, M., Rogers, Y. 1996. External cognition: how do graphical representations work? Int J Hum Comput Stud 45:185-213.

Shepard, R.N. 1978. Externalization of mental images and the act of creation. Randawa, B.S, Coffman, W.E., red. Visual learning, thinking and communication. Academic Press, New York.

Strawson, P.F. 1959. Individuals: an essay in descriptive metaphysics. Methuen, London.

Von Neumann, J. 1948/1961. General and logical theory of automata. Taub AH., red. John von Neumann: collected works. Volume V: design of computers, theory of automata and numerical analysis. Oxford, Pergamon Press: 288-326. 
Vygotsky, L. 1986. Thought and language, revised edn. MIT Press, Cambridge / 1989. Myślenie i mowa. Przeł. E. Flesznerowa i J. Fleszner. Warszawa: Biblioteka Klasyków Psychologii PWN.

Wikipedia on Kim Peek. 2009. http://en.wikipedia.org/wiki/Kim_Peek. Accessed Nov 2009.

Wittgenstein, L. 1953. Philosophical investigations. Basil Blackwell, Oxford / 2000. Dociekania filozoficzne. Przeł. B. Wolniewicz. Warszawa: Wydawnictwo Naukowe PWN.

\begin{abstract}
Why do people create extra representations to help them make sense of situations, diagrams, illustrations, instructions and problems? The obvious explanation- external representations save internal memory and com- putation-is only part of the story. I discuss seven ways external representations enhance cognitive power: they change the cost structure of the inferential landscape; they provide a structure that can serve as a shareable object of thought; they create persistent referents; they facilitate rerepresentation; they are often a more natural representation of structure than mental representations; they facilitate the computation of more explicit encoding of information; they enable the construction of arbitrarily complex structure; and they lower the cost of controlling thought-they help coordinate thought. Jointly, these functions allow people to think more powerfully with external representations than without. They allow us to think the previously unthinkable.
\end{abstract}

Keywords: External representations; Thinking; Interactivity; Sense making; Cost structure. 